\title{
MULTIPLICIDAD INTERPRETATIVA DEL MITO DE LA CABEZA CORTADA DE LA GORGONA MEDUSA Y DE SU IMAGEN CON LA RISA EN LA BOCA Y LA LENGUA FUERA
}

\section{MULTIPLE INTERPRETATIONS OF THE MYTH OF THE SEVERED HEAD OF THE GORGON MEDUSA AND ITS IMAGE WITH LAUGHTER IN THE MOUTH AND TONGUE OUT}

Francisca Martín-Cano Abreu: Escultora. francisca.m-cano@arrakis.es

\section{CURRÍCULUM VITAE}

Es ingeniera técnica electrónica por el Politécnico de La Rábida (Huelva) y psicóloga clínica por la UNED en Calatayud (Zaragoza). Escultora de renombre, tiene su obra diseminada por varios parques en España.

\section{RESUMEN}

En la mitología griega, una gorgona era un despiadado monstruo femenino a la vez que una deidad protectora procedente de los conceptos religiosos más antiguos. Su poder era tan grande que cualquiera que intentase mirarla quedaba petrificado, por lo que su imagen se ubicaba en todo tipo de lugares, desde templos a cráteras de vino, para propiciar su protección. La gorgona llevaba un cinturón de serpientes, entrelazadas como una hebilla y confrontadas entre sí. En mitos posteriores se decía que había tres gorgonas, Medusa, Esteno y Euríale, y que la única mortal de ellas, 
Medusa, tenía serpientes venenosas en lugar de cabellos como castigo por parte de la diosa Atenea. Fue decapitada por Perseo, quien después usó su cabeza como arma hasta que se la dio a la diosa Atenea para que la pusiera en su escudo, la égida. Desde la antigüedad clásica, la imagen de la cabeza de Medusa aparece representada en el artilugio que aleja el mal conocido como Gorgoneion. En este trabajo se analizan y fundamentan los fundados indicios de que en la génesis de la personalidad mítica de Medusa han podido coincidir tradiciones griegas y primitivos mitos indígenas de la Península Ibérica, además de diferentes metáforas que se asocian a la Gorgona Medusa.

\section{PALABRAS CLAVE}

Mitología - Gorgona Medusa - Perseo

\section{ABSTRACT}

TIn Greek mythology, a Gorgon was a vicious female monster while a protective deity from earliest religious concepts. His power was so great that anyone who tried to look at it would freeze, so that his image was located in all sorts of places, from temples to wine bowls, to facilitate their protection. The Gorgon wore a belt of serpents intertwined as a clasp and confronted each other. In later myths it was said that there were three Gorgons, Medusa, Esteno and Euryale are, and the only mortal of them, Medusa, had snakes instead of hair poison as punishment from the goddess Athena. She was beheaded by Perseus, who later used his head as weapon until he gave it to the goddess Athena to put it on his shield, the aegis. Since classical antiquity, the image of Medusa's head is represented in the device that drives away evil known as Gorgoneion. In this paper we analyze and base-founded indications that the genesis of the mythical character Medusa have been able to match primitive 
Greek traditions and indigenous myths of the Iberian Peninsula, and several metaphors that are associated with the Gorgon Medusa.

\section{KEY WORDS}

Mythology - Medusa Gorgon - Perseus

\section{ÍNDICE}

\section{Introducción y resumen}

2. Sentido doctrinal-histórico de que Perseo fuese en busca de la reina Medusa para cortarle la cabeza: como metáfora de la derrota del pueblo matriarcal

3. Sentido de que Perseo matase monstruos: como metáfora política-inversadesacreditadora desde la ideología patriarcal, del asesinato de mujeres

4. Sentido astronómico de que Perseo luchara contra monstruos marinos que vivían en el Occidente, al otro lado del Océano: constelaciones van al ocaso / mueren perseguidas por otras

5. Algunas imágenes de Las Gorgonas corriendo

6. Sentido de que la mirada de Medusa petrificase y que Las Greas tuvieran un solo ojo: enmascararía que eran Cíclopes / artesanas metalúrgicas que trasformaban minerales por medio del calor y construían metales bruñidos que reflejaba los rayos del sol

7. Sentido ritual de las imágenes de Medusa como máscara Gorgoneión con la risa en la boca y la lengua fuera

8. Imágenes con la risa en la boca y la lengua fuera, identificadas con Diosas o sus Sacerdotisas 
9. La risa orgiástica de Sacerdotisas, para hacer llover y germinar la semilla, también modelo de la risa orgiástica de Sacerdotes cristianos, para resucitar a Jesús

10. Mujeres del siglo XX reivindican la liberación a través de la risa asociada al placer sexual y el derecho a ser obscenas

11. Bibliografía

\section{TEXTO:}

\section{Introducción y resumen}

En este trabajo tratamos divulgar y profundizar en las interpretaciones dadas por otros investigadores respecto a los enredados mitos de Las Gorgonas, así como buscar nuevas vías de interpretación a las dadas respecto a las imágenes del Gorgoneión, conjuntos que consideramos encierran ideas absolutamente diferentes.

Para interpretar los diversos sentidos de los episodios mitológicos en los que se ven envueltas, nos guiamos por los razonamientos bien fundamentados emitidos por algunos expertos que los han interpretado metafóricamente.

Ellos consideran que sus autores, los literatos y poetas: Homero, Hesíodo, Píndaro, Eurípides, Ovidio... inventaron deliberadamente y a lo largo de los siglos, los episodios mitológicos sobre Las Gorgonas, compartiendo un mismo paradigma (en el sentido de inventado, con acontecimientos y protagonistas en eventos concretos que se repiten. Pero de los que no se puede precisar que sucediesen, ni en una fecha ni en un lugar determinado). Y con la finalidad de transmitir a la sociedad unos valores al servicio de los intereses de la civilización patriarcal griega. 
Civilización griega que se originó en las islas del mar Egeo, tras invadirlas primero los Aqueos en el siglo XII adne y después los Dorios. Los invasores colonizaron el territorio, donde había florecido la civilización matriarcal cretense, cuya población autónoma era de mayor nivel cultural que la de los invasores. Y durante más de mil años, los líderes griegos se dedicaron, fundamentalmente, a seguir ampliando de forma violenta su área de dominio en todo el Mediterráneo: los Balcanes, Asia Menor, norte de África, Italia.... Después, daban una nueva organización política a las regiones conquistadas, basada en el patriarcado, en la que los soberanos ejercían el poder de manera enérgica. E imponían su régimen ayudados por literatos y poetas y otros artistas, que ilustraban y concretizaban el modelo antifeminista de su sistema patriarcal, lo que daba fundamento a su ideología política y legitimaba las acciones agresivas y el poder absoluto.

Por lo que no extraña, que acorde a la ideología machista, los mitólogos construyeran unos personajes, que a pesar de que mantenían conductas agresivas contra el poder femenino, salían impunes y sus tropelías eran consideradas heroicas. Lo que evidencia cuales eran las conductas y los valores discriminativos, que la ideología patriarcal defendía y que reforzaban en la sociedad, para, por mimetismo, cada género asumiesen las conductas apropiadas del modelo.

De forma que, describen a Perseo, como un héroe agradecido a su bienhechor el rey Polidectes por el buen trato recibido, que parte a buscar, junto con el ejército griego, el trofeo de la reina Medusa, para entregárselo como regalo de bodas. Y simultáneamente, lo muestran como un héroe desagradecido a las bondades de las mujeres, a las que paga, con el engaño, la crueldad, la difamación y el robo de sus propiedades: Perseo robó el ojo y diente a las Greas y robó el huerto a Las Atlántidas / Las Pléyadas / Las Nymphas, a pesar de los valiosos regalos mágicos recibidos: casco metálico, zurrón y sandalias. 
Siendo el regalo de las Greas a Perseo, de objetos metálicos y de cuero, metáforas de que enseñaron a los griegos la metalurgia y las técnicas artesanales del cuero. Y puesto que usó los regalos para matar a la reina Medusa, sería metáfora que usó los conocimientos adquiridos en contra de sus maestras.

Y el robo por parte de Perseo, del huerto y otros objetos de las mujeres visitadas, sería metáfora de la apropiación patriarcal de las profesiones que estaban en manos femeninas: el cuidado de los campos de cultivo y sus frutos; los Santuarios donde acumulaban el conocimiento y las riquezas; las minas de minerales y sus beneficios; así como los talleres metalúrgicos y artesanales.

Y además, los mitólogos, con metáfora inversa desacreditadora, difaman a las mujeres. Así, la reina Medusa es descrita como un monstruo cuya mirada petrificaba. Es decir, que metafóricamente está diciendo, que portaba algo como un ojo que llenaba de admiración / petrificaba a quienes la miraban y que aterrorizaba (bien porque era como una centella que enviaba fuego que achicharraba y lo usaba para castigar, o bien porque lo usaba para defenderse al reflejar la luz y deslumbrar). Llevaba algo de metal bruñido que brillaba al reflejar los rayos del sol. O portaba una especie de candil con mecha impregnada en grasa de animal o en aceite, que ardía. Y en el primer caso, lo usaría como espejo que reflejaría los rayos solares, que al ser dirigidos contra los barcos de los invasores, los deslumbrarían y les impedirían ver los peligros de la costa escarpada y naufragarían. Y en el segundo, lo usaría para encender un artilugio como flecha, que al ser lanzado contra el enemigo, lo achicharraría. 
O bien Medusa estaba asociada a una estrella, que cuando surgía como "un maligno ojo", se producía un fenómeno relacionado con las piedras (meteoritos) que aterrorizaban a los humanos.

Mientras que para interpretar el significado de las imágenes del Gorgoneión y de Las Gorgonas, nos alejamos de las interpretaciones clásicas.

Nuestras investigaciones nos han hecho encontrar otras razones respecto al hecho de que las más arcaicas obras de arte de la Gorgona Medusa, bien en imágenes de cuerpo entero, o de la cabeza aislada / Gorgoneión, fuera representada con rasgos híbridos de animal y mujer, con sonrisa en la boca, lengua fuera, colmillos de jabalí, con cabellos que evocan tentáculos, señal en la frente, alas de aves pero de oro, sandalias aladas o en actitud de correr o volar.

Para nosotros los atributos de estas imágenes contienen, componentes simbólicos relacionados con el universo religioso matriarcal muy complejo, reflejo de sus múltiples personalizaciones, incluida la personalización astronómica.

Representarían, en forma resumida, tanto:

1. Al animal marino medusa que flota libremente por el océano, es venenoso, parece una cabeza de gelatina transparente o coloreada, en forma de campana / casco / yelmo, que es su cuerpo, con tentáculos como cimera / penacho que surge de un casco. Y es epónimo de la reina / Diosa Medusa [con el significado de "Señora", o "La Dominadora", o "La Soberana" o "Gobernante" o "Reina" o "Sabiduría" (según Campbell 1992: 176 y Husain, 1997: 61)]. 
2. A la vez, serían la representación de la constelación animalística: Cabeza de Medusa (actualmente desaparecida de las Guías de Estrellas) cuyas estrellas estaban personificadas por la reina / Diosa Medusa y sus hermanas las Gorgonas. Y constelación de animal marino, que junto a otras constelaciones, se mueven / se desplazan / corren / vuelan / nadan por la bóveda del cielo nocturno, por el Océano Celeste y por el Mar o Río Celeste / la Vía Láctea que lo atraviesa. De ahí el origen de los atributos metafóricos de las imágenes que las reflejan, como alas o sandalias aladas o la actitud de correr o volar, para indicar que se desplazaban por el cielo. Y constelaciones, muchas con nombres de animales acuáticos, bautizadas desde la más remota antigüedad: Delfín, Ballena, Piscis, Cáncer / Cangrejo, Pato o Cisne, porque se movían por el Océano y el Río Celeste, al igual que los animales oceánicos u acuáticos lo hacen por los océanos y ríos terrestres.

3. También la cabeza aislada con la lengua fuera y la sonrisa en la boca, sería imagen de mujeres cuando participaban en rituales orgiásticos secretos. En esos ritos en los que soltaban la lengua [y que formaban parte de las representaciones trágico-cómicas de los Misterios sagrados (como en los Gephyrismi de los Misterios Eleusinos, en las Stenia / Estenia de los Misterios Tesmoforias, en las disputas burlescas de los Misterios de la Diosa Damia)] (origen de las Comedias y las Sátiras), sacaban la lengua y sonreían con finalidad mágica-metafórica. Y los celebraban cuando la constelación Cabeza de Medusa, ocupaba una precisa situación en el horizonte, bien al atardecer o al amanecer de determinado día de fiesta del año. Cuando, estadísticamente, se esperaba que coincidentes, aparecieran ciertos fenómenos, benéficos o maléficos para la agricultura. Con el ritual orgiástico, se trataría de propiciar los fenómenos benéficos, o conseguir protección contra los maléficos. Por lo tanto, las imágenes sonrientes recordarían a las conocedoras de la simbología exacta, cuándo celebrarlos y cómo soltar la lengua y sonreír con sus «dos sonrisas». 
Los artistas, al igual que los mitólogos patriarcales, se inspiraron en las obras de arte de las autoras matriarcales, para seguir reproduciendo los mitos patriarcales. Pero al desconocer el fundamento metafórico que estaba en su origen y el porqué las imágenes eran híbridas o tenían ciertos atributos, no respetaron algunos.

Por ejemplo, algunas imágenes las presentan arrodilladas, cuando en principio imitaban a las Gorgonas que tenían actitud de correr o volar (en alusión a la constelación animalística, personificada por una mujer, que se desplazaba por el cielo). Otros artistas patriarcales, interpretaron los cabellos-tentáculos de Medusa (que aludía al animal marino medusa), con diferentes variantes: como serpientes, como rayos de la Luna, como cabellos desgreñados, como púas, como rizos, trenzas, o espigas, o como casco con cimera. Otros artistas más tardíos, desconociendo la explicación precisa de que los gestos de la sonrisa y la lengua fuera (al menos no hemos encontrado ninguna información explícita, o que podamos deducir del contexto mitológico), en realidad, invitaban a la «risa vertical orgiástica» y a «soltar palabras soeces» o al «cunnilingus»), hicieron evolucionar el Gorgoneión, hacia tipos de bellas mujeres y dejaron de representarlas con tales atributos.

\section{Sentido doctrinal-histórico de que Perseo fuese en busca de la reina}

\section{Medusa para cortarle la cabeza: como metáfora de la derrota del pueblo matriarcal}

En una primera interpretación doctrinal-histórica del mito del héroe Perseo, algunos intérpretes afirman que es un ejemplo de las muchas epopeyas inventadas a principios de tiempos históricos y protagonizadas por un héroe, que invade regiones en donde gobernaban mujeres muy poderosas. Es decir en donde estaba vigente la cultura matriarcal. Y lo hace en busca de un trofeo para regalárselo, en este caso, al rey Polidectes. Lo que evidencia que no iniciaba el viaje como un comerciante o como 
un colono pacífico que emigraba para asentarse en otro lugar, razones que llevaban a viajar. Ya que, como afirma Lara Peinado en (1990, 56): "De acuerdo con la mentalidad griega, el comercio era algo denigrante y los comerciantes gente de baja condición. Homero no escapó a esta opinión, presentado la actividad mercantil como algo deshonroso, hasta el extremo de defender mucho más la piratería que el comercio, opinión que también siguieron Hesíodo, Aristóteles y Tucídides." Sino que refiere la emigración violenta-invasión patriarcal de los griegos para despojar a los habitantes de las regiones asaltadas, de sus trofeos $=$ conocimientos, propiedades $\mathrm{y}$ riquezas.

Corrobora esta interpretación, la reflexión de Campbell en (1992, 175): "El profesor Hammond asigna al rey histórico Perseo de Micenas una fecha alr. 1290 a.C., como el fundador de una dinastía; y Robert Graves -cuyos dos volúmenes Los mitos griegos son especialmente interesantes por sus sugerentes aplicaciones históricas- propone que la leyenda de Perseo decapitando a Medusa significa, especialmente, que «los helenos devastaron los principales santuarios de la diosa» $\mathrm{y}$ «despojaron a sus sacerdotisas de sus máscaras de Gorgona», siendo éstas últimas rostros apotropaicos que llevaban para atemorizar a los profanos. Es decir, al principio del siglo XIII a.C. tuvo lugar una ruptura histórica, una especie de trauma sociológico..."

De forma que tanto Perseo, como otros héroes protagonistas de epopeyas míticas: Hércules, Jasón, Odiseo... representaban al pueblo patriarcal que se apoderaba por la violencia de regiones donde estaban establecidos pueblos seguidores del régimen matriarcal.

En una primera etapa, esas mujeres se volvieron guerreras para combatir las invasiones, hasta que al final sucumbían. "Por su parte, Diodoro de Sicilia presenta a Las Gorgonas como un pueblo belicoso que en cierta ocasión luchó con el de las 
Amazonas, siendo vencido por éste; según Diodoro, las Gorgonas, atacadas después por Perseo, habían perecido definitivamente a manos de Hércules." (Anónimo, 2004b).

Por lo que la decapitación de Medusa por Perseo, ejemplificaría el vencimiento y el descabezamiento de las reinas que gobernaban en determinada región de régimen matriarcal, por parte de pueblos patriarcales. Y el que cortase su cabeza sonriente y con lengua fuera, enmascararía que se cortaba a las mujeres el derecho a poder soltar la lengua y reír cuando quisieran, a ser soeces, a ser impúdicas, a ser obscenas. Es decir que en el patriarcado se cercenaba en las mujeres el poder disfrutar de su sexualidad libremente.

\section{Sentido de que Perseo matase monstruos: como metáfora política- inversa-desacreditadora desde la ideología patriarcal, del asesinato de mujeres}

El mito del héroe que mata monstruos, traduciría con metáfora eterna y sentido inverso desacreditador, las acciones de los agresivos pueblos patriarcales, en contra del poder femenino, mientras se prestigiaba el proceso de conquista. Es decir, que las crueles acciones de Perseo, que la visión patriarcal traduce como hazañas heroicas en contra de monstruos, es otro ejemplo más de la estrategia del agresivo vencedor, que mediante el descrédito y difamación de la víctima, usaba el mecanismo psicológico de inversión para justificar su violencia y desprecio por las mujeres.

El desacreditar a las reinas y defensoras de pueblos matriarcales pacíficos, como monstruos dañinos y horripilantes, servía para justificar las acciones emprendidas 
por los pueblos invasores violentos, contra pueblos superiores a los que se odiaba, y sobre todo se envidiaba por sus conocimientos o se codiciaba por sus riquezas. Y así Perseo-pueblo vencedor patriarcal, encontraba plena justificación para robar las propiedades y riquezas de las Gorgonas / monstruos matriarcales, además de maltratarlas, violarlas y asesinarlas. Y con ello arrebatarles su libertad y su autonomía, ipara así jsalvar a la humanidad!

Con ello se reforzaba el modelo patriarcal que implantaba la impunidad de las acciones infamantes de los agresores y se imponía la indefensión de las mujeres para que aceptasen sumisamente las atrocidades.

Por lo tanto, la lucha de Perseo contra las monstruosas Gorgonas enmascara la lucha del poder patriarcal contra el poder matriarcal.

Visión compartida por J. Ma Aguirre en (2003): "El combate masculino-femenino. Otro aspecto importante constituyente del mito es su carácter agonístico. Lo horrendo es el elemento con el que hay que combatir".

Y confirmada por Mayr $(1989,27)$ : "toda la filosofía y teología greco-occidentales muestran ese dualismo matriarcal-patriarcal, así como el vencimiento del primero por el último."

En palabras de Atienza en (1991, 392): "Los valores emanados de lo femenino, del ancestral culto a la Magna Mater, fueron relegados, cuando no perseguidos y destruidos con toda la saña de lo odiado y temido a la vez."

Así la mujer iba perdiendo su poder milenario, su autoestima, sus derechos. Mientras los varones, después de arrebatarles sus propiedades, asesinarlas y apropiarse de sus 
Santuarios, se encargaban del culto, de las profesiones, talleres, riquezas femeninas y extendían su dominio a todos los campos hasta subordinarlas e imponer las costumbres y cultos patriarcales.

Evidencia que los diferentes episodios míticos protagonizados por Las Gorgonas se inventaron desde la visión interesada y sesgada patriarcal para subordinar lo femenino, porque hay pruebas flagrantes.

Por ejemplo el episodio que recoge Ovidio en su Metamorfosis, narra que Medusa era una muchacha de gran belleza. Y aunque fue violada por Poseidón en el Templo de la Diosa Atenea / Minerva, es la Diosa la que: "Encolerizada por tamaño acto de impiedad, la diosa la había transformado en un monstruo." (Mercedes Aguirre, 2004).

¡Es evidente que si el mito, en un ejercicio más de hipocresía machista, propone a la virginal Atenea, castigando a la víctima del violador porque le ofende que hiciera el amor en su Templo, en vez de castigar al que la atropella, adopta el mismo modelo táctico propio del patriarcado. Así que la visión machista, justifica y santifica el castigo a la víctima del atropello masculino, por parte de una Diosa que desafía la justicia en contra de los derechos femeninos. Además, castiga la sexualidad femenina y potencia la masculina, en un afán aleccionador que refuerza la conducta agresiva y de violación por parte del varón y como hazaña a imitar.

Y encima, como otra estrategia llena de malicia del mitólogo patriarcal, y para modelar la rivalidad entre mujeres ipor la belleza estética!, usa la fórmula de degradar a la Diosa Atenea / Minerva, al mostrarla preocupada únicamente por el aspecto de belleza física, cuando en la mitología anterior, entre sus muchas facultades, se le atribuía ser: la Inventora de las Ciencias, los Oficios y las Industrias (Organa) que había dado principio a las manufacturas y a las artes, Presidenta de la 
Medicina (Médica), Patrona de los Artesanos (Ergana), Inspiradora de los Oradores (Agoraia), Patrona de la Agricultura, que hizo el don del olivo a los atenienses, Inventora del Arado (Agripha), del rastrillo, de la cuadriga, y de las artes de domesticación de animales, de la flauta, de la trompeta, de la construcción de barcos y de la fabricación de zapatos (Anónimo 2004g y Sáinz de Robles, 1959).

En cualquier caso, todos estos mitos que se extendieron por el Mediterráneo, eran los referentes que tenían entonces las mujeres y varones de las sociedades griegas, con lo que se transmitían conductas que reforzaban: la rivalidad femenina y no la solidaridad; la aceptación de convertirse en objetos bellos para estimular el deseo sexual masculino; el que enfocaran su mente en problemas triviales estéticos para seducir; el evitar que se interesaran por papeles más activos. Y a la vez que las inducía a aceptar la desigualdad respecto a los varones, se promocionaban conductas para que los varones fueran agresivos, violentos y se dedicaran a robar, violar, engañar, despreciar, denigrar..., impunemente a las mujeres...

Todos, mitos discriminadores que se transmitieron de generación en generación y contribuyeron a formar las identidades estereotipadas de cada género y propias del patriarcado.

Respecto a otras interpretaciones del viaje de Perseo matando monstruos, algunos mitólogos modernos han hecho observaciones muy diferentes a las nuestras (cada uno ve lo que sabe). Y consideran que codificarían: "Los peligros del mar" para el navegante que hace una travesía en su barco con finalidad comercial." O: "Un intento de simbolizar al hombre superando el miedo". Otros creen que reflejaría: "Los obstáculos con los que se encuentra un varón para descubrir los elementos femeninos que lleva en su interior". Por el contrario, otros defienden: "El desafío del héroe para afrontar el equilibrio interior". O bien concretizarían: "La metáfora de la entrada de 
un joven en la virilidad". (Afirmaciones extraídas de los textos de Mercedes Aguirre, Husain y otros autores).

\section{Sentido astronómico de que Perseo luchara contra monstruos marinos que vivían en el Occidente, al otro lado del Océano: constelaciones van al ocaso / mueren perseguidas por otras}

Según Hesíodo las Gorgonas vivían en un lugar lejano del Occidente. Más exactamente: "Las Górgonas vivían en la orilla del famoso océano, en la extremidad de la noche donde se encuentran las Hespérides de voz sonora, cerca del país de los muertos."(Anónimo, 20004e). Y aunque unos supongan ese lugar se refiere a una región del Ponto Euxino / mar Negro y otros a un territorio en las cercanías del lago Tritonis, lago mítico de Las Hespéridas, localizado en Las Syrtes, cerca de Cirenaica, norte de África, el caso es que la referencia a las Hespéridas nos hace deducir que personificaban una constelación.

Es decir que Las Gorgonas personificarían una constelación, cercana a constelación de Las Hespérides. Confirmarían nuestra deducción varios indicios:

A. Por el sentido doble que tiene la palabra océano: uno se refiere al océano terrestre y otro al Océano Celeste o bóveda celeste nocturna. Por lo que la expresión "la orilla del famoso océano", se referiría a que habitan en la orilla del Océano Celeste, es decir justo dentro de la Vía Láctea, nombre que también denomina al Río Celeste que atraviesa la bóveda celeste. Y cerca "del país de los muertos", aludiría a que se refería al momento en que la constelación se encontraba cerca del horizonte, dado que más allá del horizonte está el mundo subterráneo, lugar en el que se entierran a los muertos / el Más Allá de Occidente (y lugar al que también van todas las constelaciones y demás astros en su viaje diario, cuando se van al ocaso: surgen por 
el este / oriente atravesando el horizonte y se ocultan por el oeste / occidente, traspasando el horizonte).

B. Lo confirmaría el hecho de que los otros personajes míticos, que coprotagonizan las aventuras con las Gorgonas, también denominan constelaciones y en sus aventuras: "... los antiguos veían en las constelaciones Casiopea, Andrómeda, Perseo, Pegaso, y Cefeo, la figura de una leyenda mitológica". (E. U. I., Tomo 5, 1088: 467).

Así, personifican constelaciones:

1. La BALLENA / CETUS / Keto (epónima de la reina Cetus "Ballena" de Cerdeña, que según el mito fue convertida por su padre en monstruo marino Glaucetes. Era madre de las Gorgonas y de las Greas junto con su hermano Forco, lo que evidencia los usos sucesorios del matriarcado. Y fue matada / convertida en piedra / meduseada $=$ petrificada $=$ asombrada $=$ admirada, por Perseo al enseñarle la cabeza cortada de la reina Medusa, su propia hija).

2. La mortal reina MEDUSA, descabezada por Perseo (hermana de las inmortales Gorgonas Euríale y Esteno y de las tres Greas, e hijas de la reina de Cerdeña Cetus "Ballena" y de su esposo-hermano el Dios del mar Forcis / Forco / Forcir).

Y efectivamente, Las Gorgonas personifican una constelación con el nombre de la Cabeza de Medusa, que aunque ha sido eliminada de las actuales Guías de Estrellas del cielo nocturno, estuvo vigente y fue publicada en el año 1985, según la foto del planisferio de la E. U. I., Tomo 55, en la voz Siderología Cuadro 1. Y lo confirman los enciclopedistas de la voz Gorgona de la E. U. I. Tomo 26 (1988, 707), en la que leemos: "Estrella de la constelación de Medusa". 
Cuadro 1. Planisferio de la E. U. I. (1988, 707), Tomo 55, en la voz Siderología

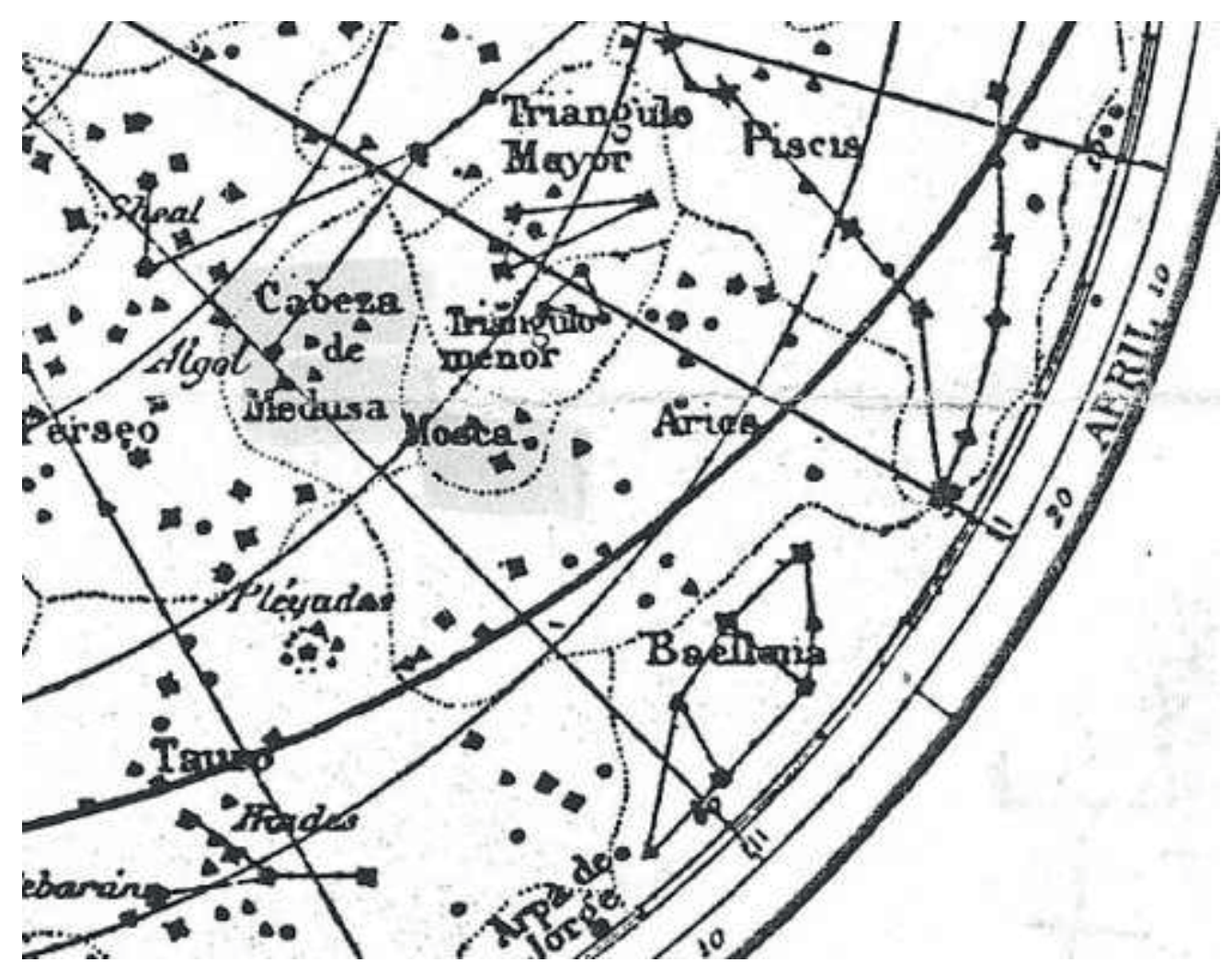

La interpretación astronómica da razón del porqué se diga que Medusa era la única de las hermanas visible para los humanos. Con ello están recogiendo el hecho astronómico de que la constelación Cabeza de Medusa era casi circumpolar (una estrella es circumpolar cuando nunca desaparece bajo el horizonte, para las regiones en esa misma latitud). De forma que, mientras aún en el período en que la constelación es invisible, porque las estrellas personificadas por el resto de las hermanas Gorgonas permanecían bajo el horizonte, Medusa, sí que era visible, ya que era circumpolar. Y esta misma interpretación astronómica explica el hecho mítico de que se diga que Pegaso surgió del tronco de Medusa. Ya que la constelación de Pegaso surge, cuando gran parte de las estrellas de la constelación de Medusa se va al ocaso (las personificadas por sus hermanas, no la estrella personificada por Medusa, que era circumpolar). 
3. Y sus hermanas-cisnes Las Greas a CISNE (asociadas a los delfines, constelación Delfín cercana).

4. El caballo alado PEGASO (hijo de Medusa y Poseidón, tras violarla convertido en pájaro).

5. El griego PERSEO (que mató a la reina Medusa y se casó con la heredera de Etiopía, Andrómeda).

6. La princesa etíope ANDRÓMEDA, que fue atada por las Nereidas a una roca para apaciguar el furor del monstruo Ballena. Pero cuando iba a ser devorada, Perseo en su Pegaso mató al monstruo, rompió las cadenas, la restituyó a su madre y se casó con ella.

7. La reina de Etiopía CASIOPEA, que tuvo la osadía de disputar el premio de belleza a Juno y a las Nereidas [cincuenta hermanas Ninfas del Mar (Celeste / Vía Láctea $=$ estrellas de constelaciones en la Vía Láctea] y de vanagloriarse de ser la más bella, por lo que irritado Poseidón / Neptuno, desató una inundación e hizo aparecer el monstruo marino: la ballena destructora para devastar la Tierra.

8. Y su esposo el rey CEFEO (padres de la princesa).

9. Las PLÉYADAS / Atlántidas (visitadas por Perseo a las que les robó el huerto).

10. Las HESPÉRIDAS que vivían junto a las Gorgonas. 
C. Así que el enfrentamiento de los monstruos de las Gorgonas, de sus hermanas las Greas, de la Ballena... con Perseo tiene una explicación astronómica: el viaje de las constelaciones animalísticas en su recorrido diario por el cielo nocturno, perseguidas por la constelación de Perseo. De forma similar ha sido interpretado el viaje de Rama de la epopeya Ramayana: "... no es más que una ficción de geografía astronómica, aunque cree que bajo esta fábula podría ocultarse algún héroe verdadero." (E. U. I., Tomo 49, 1991, 488).

Las diferentes acciones agresivas de Perseo contra monstruos femeninos, expresarían sus diferentes posiciones, con respecto a las constelaciones animalísticas a lo largo del año, bien al atardecer o al amanecer de determinados días de fiesta (posiciones que se fijaron hace 5.300 años en 22 días de fiesta y que servían para anunciar los fenómenos atmosféricos cíclicos. Benéficos o maléficos, esperados estadísticamente para cada situación estelar en que se "centralizaron" los diferentes hechos astronómicos señalados).

De manera que se codificaba que el ocaso de una constelación femenina, seguida por la de Perseo, o coincidente con el resurgir de Perseo, con el mito de que éste era el causante de la muerte del monstruo / del ocaso de la constelación animalística.

Por ejemplo, cuando Perseo se apodera del huerto de Las Pléyadas, aparte de enmascarar el hecho histórico de la apropiación patriarcal de las posesiones femeninas, expresaría el hecho astronómico de que la constelación de Perseo queda por encima de Las Pléyadas cuando éstas se van al ocaso, en determinado momento del año (hace 5.300 años el atardecer del 14 de febrero, hoy 1 de mayo).

El mito de Perseo apoderándose del diente y ojo de las hermanas cisnes Greas / Grayas / Graias, se explicaría con la situación estelar de que la constelación Cisne se 
iba al ocaso perseguida por Perseo (el atardecer del 23 de octubre de hace 5.300 años, hoy 8 de enero)

Y cuando mata a la Ballena, con el hecho astronómico de que ésta se va al ocaso perseguida por la constelación de Perseo (el atardecer del 10 de noviembre de hace 5.300 años, hoy 25 de enero). Y tal mito estaría reflejado en el Cuadro 2.

\section{Cuadro 2}

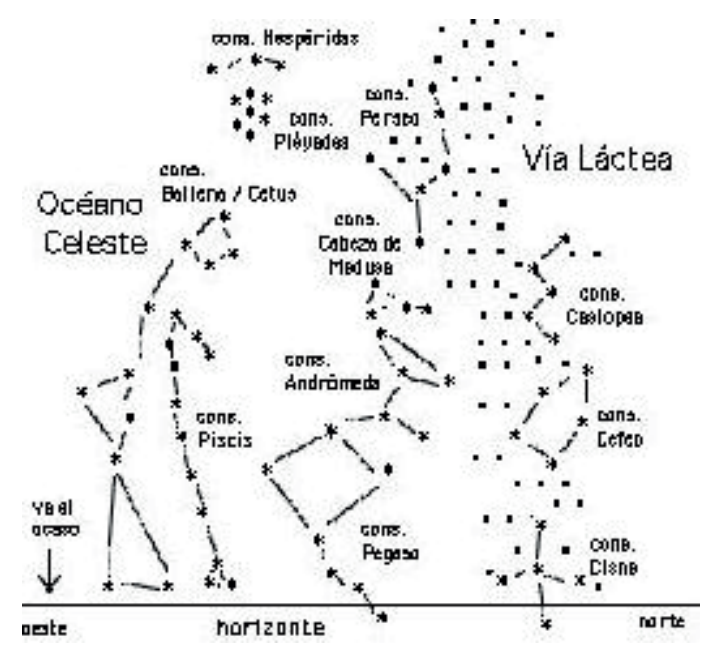

Situación estelar vespertina del 10 de noviembre de hace 5.300 años, hoy 25 de enero, con la constelación Cetus yéndose al ocaso por occidente, seguida por la de Perseo (junto con la de Piscis, Pegaso, Andrómeda, Cisne, Cefeo, Casiopea, Cabeza de Medusa, Pléyadas, Hespéridas...). Concretizada en el mito de que el monstruo Ballena es petrificado por Perseo tras enseñarle la Cabeza de Medusa = el ocaso de la constelación de la reina Cetus es perseguido por las constelaciones Perseo y Cabeza de Medusa.

D. También la explicación astronómica de que Las Gorgonas den nombre a una constelación, da razón del porqué hayan sido consideradas personificación de las 
"negras nubes preñadas de lluvia y pedrisco", y sus hermanas símbolo de las nubes primaverales. Según la E. U. I., Tomo 267 (1988, 1166): "Por otra parte, y teniendo en cuenta que los cisnes simbolizan las nubes, se puede creer que estos genios representan las nubes claras del tiempo benigno, especialmente de la puesta del sol, mientras que sus hermanas, las Gorgonas, personifican las negras nubes preñadas de lluvia y pedrisco."

En realidad creer que "representan las nubes claras del tiempo benigno", es una mala interpretación dada por intérpretes desconocedores de lo que indicaba las diferentes posiciones cíclicas de las constelaciones a largo del año, anunciadores de fenómenos, unos maléficos y otros benéficos. Más exacto sería decir que tal personaje animalístico (las Greas en forma de cisnes), personificaban o representaban una constelación animalística (Cisne), que en determinada posición cíclica, era coincidente con el tiempo en que se presentaba tal fenómeno.

Así que cuando se producía al atardecer el orto vespertino por el este, tras la puesta del Sol, de la constelación Cisne, personificada por las hermanas de las Gorgonas, los cisnes Greas, era coincidente con el tiempo en que aparecían el fenómeno benéfico de los vientos suaves, cuando daba inicio la floración y la emigración de la primavera (situación estelar del 1 de marzo de hace 5.300 años, hoy tal situación estelar tiene lugar el 15 de mayo).

Mientras que cuando se producía cierto atardecer del año, el orto vespertino por el este de la constelación de Medusa (el 1 de junio de hace 5.300 años, hoy 15 de agosto), su aparición anunciaba / era coincidente con el fenómeno "terrorífico" de la lluvia negra de pedrisco / de meteoritos (cuando caían a tierra la lluvia de estrellas de las Perseidas / las Lágrimas de san Lorenzo que hoy tienen lugar del 11 al 15 de agosto sobre las 24 horas). 
De forma que el mito anunciaba el fenómeno que estadísticamente se esperaba fuera enviado por la Divinidad, coincidiendo con esa situación estelar. (Por lo que dado que eran diferentes los fenómenos que se presentaban a lo largo del año y cíclicamente, podían estar preparados para los benéficos y tomarían medidas para propiciar a la Divinidad para que no fuera tan cruel y no enviara fenómenos maléficos (con actos mágicos).

También a Perseo se le podría considerar como personificación del Sol y sus aventuras matando monstruos podrían ser considerados como que: la aparición del Sol al amanecer, vencía a las constelaciones nocturnas (femeninas), animalísticas, de objetos, personas..., personificadas por Diosas. Por lo que el vencimiento de Perseo sobre todos los monstruos, simbolizaría que la luz del Sol hace desaparecer la visión de las constelaciones nocturnas.

Si los mitólogos conocieran la interpretación astronómica y climática de las Gorgonas y demás coprotagonistas míticos, comprenderían: el porqué el mito dice que vivían en Occidente, junto al "Más Allá", así como el verdadero alcance de que estuvieran asociadas a "fenómenos atmosféricos", o tuvieran una "función apotropaica" "con su doble vertiente maléfica/benéfica", que para nosotros es obvia, como cuando Mercedes Aguirre reflexiona (2004): "Tras la descripción de sus rasgos más sobresalientes, podemos preguntarnos ahora qué simbolizan estos seres monstruosos, las Gorgonas, que aparecen en el mito vinculados a un lugar geográfico -el Occidente- y provistos de esos atributos destinados fundamentalmente a provocar el horror. Las interpretaciones ya desde la antigüedad fueron de lo más variado, pero siempre estaban encaminadas a asociarlas a algún tipo de miedo, bien sea el miedo a los animales -al león por ejemplo- o a ciertos fenómenos atmosféricos -tormentas, rayos-. Su función apotropaica, por otro lado, les confería un carácter no del todo 
negativo, sino más bien ambivalente -como cree Moreau-, con rasgos comparables a la Madre Tierra con su doble vertiente maléfica/benéfica." (...) "Pues hacia occidente, hacia los límites de la noche, se hallaban para los griegos esos lugares donde confluían lo celeste y lo subterráneo, el Más Allá y el profundo Tártaro. Ya hemos visto cómo Homero sitúa la cabeza de Medusa en los propios Infiernos, en el Hades."

\section{Algunas imágenes de Las Gorgonas corriendo}

En el Cuadro 3 ilustramos algunas imágenes de la Gorgona Medusa corriendo (símbolo de que se desplazaba por el cielo), con lengua fuera y peinada con cabellos que caen como trenzas, rizos o serpientes, que recuerdan los tentáculos colgantes del animal marino medusa.

Curiosamente, la postura corriendo, la lengua fuera, las serpientes es similar a la que adopta la Diosa Coyolxauqui de la cultura azteca de México, que entre sus múltiples imágenes también se representaba así (Figura 6: foto publicada por Anónimo, 2005, tras rehacer el rompecabezas de sus miembros desmembrados), de quien el mito narra que fue decapitada igual que Medusa. "Su hermano y enemigo Huitzilopochtli había decapitado a Coyolxauhqui y al ser despeñada se desmembró." (Anónimo, 2005).

El hecho de que tanto en México como en culturas de principios de época histórica de la cuenca del Mediterráneo, existan coincidencias de obras de arte o de mitos, a pesar de ser regiones muy alejadas entre sí en el espacio y en el tiempo, se debe a que: "... los temas fundamentales de la mitología han sido constantes y universales..." (Campbell, 1991: 31), como saben los estudiosos de mitologías, de obras de arte y de religiones prehistóricas y paganas de todo el universo. 
En todo el universo nuestros ancestros, cuando descubrieron el comportamiento cíclico de las constelaciones asociadas al clima, cuando inventaron los mitos que los reflejaban, así como cuando realizaron las obras de arte y los ritos inspirados en tales mitos y situaciones astronómicas, habían dado un sentido metafórico a todas las descripciones y acciones. Si lo hacían así era porque imaginaban que tendrían función mágica para propiciar por sustitución o identificación, el fenómeno benéfico que se deseaba que la Divinidad enviara o que protegiera contera el maléfico. Y que encubierto como mitos religiosos y rituales de la religión agrícola extendieron con sus emigraciones. Como dice Westhein en (1988- 100): "Lo que el Cielo estrellado descubría al hombre precortesiano eran indicios, presagios, revelaciones de los planes divinos. Y si la posición de los astros le anunciaba malas cosechas, sequía, hambre, tenía que hacer esfuerzos supremos por reconciliar al dios de la lluvia, a las deidades de la fecundidad o a cualquier otro numen competente en el caso respectivo, para evitar que dejaran de ejercer sus funciones."

\section{Cuadro 3}

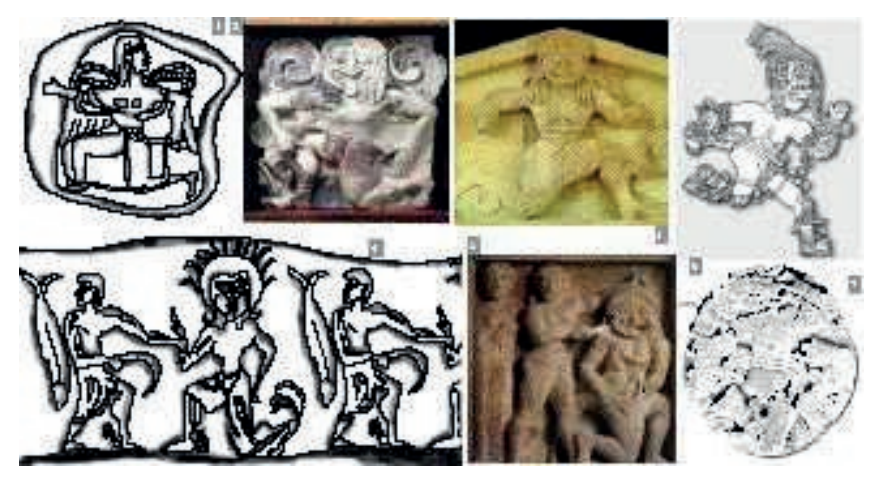

Figura 1: Gorgona Medusa o Arpía, con alas en actitud de correr o volar y serpientes, en moneda de Arctonnesos / Cízico, La Misia de Asia Menor, hoy Artaki. Siglo V adne 
Figura 2: Gorgona Medusa sonriendo, con lengua fuera, con alas y sandalias aladas en actitud de correr o volar, cabellos-trenzas que evocan tentáculos y señal en la frente, terracota del Atenaicón, Templo de la Diosa Atenea Pallas de Siracusa. Año 560 adne

Figura 3: Gorgona Medusa sonriendo, con lengua fuera, sandalias aladas en actitud de correr o volar, cabellos-trenzas que evocan tentáculos y con serpientes (a su lado Crisaor y panteras enfrentadas), relieve en el frontón del Templo de Artemisa en la isla del archipiélago Jónico Corcira / Kerkyra / Melania / Sicheria / Eskeria / Scheria / Esqueria / Feacia de Iliria, hoy Corfú. Siglo VI adne

Figura 4: Gorgona Medusa, con sandalias aladas en actitud de correr o volar, rayos en la cabeza, a punto de ser decapitada con una hoz por Perseo que le agarra el brazo. Y para no mirarla dirige su vista hacia un pez-espejo. Escena desarrollada de un sello encontrado en Bagdad, Mesopotamia. Posterior al 600 dne

Figura 5: Gorgona Medusa sonriendo, con lengua fuera, arrodillada, a punto de ser decapitada con espada por Perseo, sosteniendo un pequeño Pegaso (aunque el mito considera que brotó de su tronco decapitado), metopa del Templo de Selinunte. Año 530 adne

Figuras 6 y 7: Diosa Coyolxauhqui con lengua fuera, casco con cimera / penacho y serpientes, en actitud de correr o volar (dibujo reconstruido por Anónimo, 2005 partiendo de la imagen desmembrada tallada en relieve en la piedra circular hallada enterrada bajo la pirámide gemela de Tenochtitlán)

\section{Sentido de que la mirada de Medusa petrificase y que Las Greas tuvieran un solo ojo: enmascararía que eran Cíclopes / artesanas}




\section{metalúrgicas que trasformaban minerales por medio del calor y construían metales bruñidos que reflejaba los rayos del sol}

Los mitos clásicos narran que la Gorgona Medusa era un ser peligroso provisto de una mirada capaz de convertir a quien la mirase en piedra y sus tres hermanas las Greas / Grayas tenían un solo ojo.

Para nosotros es evidente que ambos son un antecedente del mito más elaborado de los Cíclopes, que tenían un solo ojo y eran artesanos metalúrgicos que fabricaban armas mágicas metálicas, como yelmo / casco para hacerse invisible, y tridente para gobernar las tempestades, además de ser fabricantes de espejos y otros objetos metálicos. Leemos al respecto en Grossato (2000, 73): "Más conocidas son ciertamente, por un lado la leyenda de los Cíclopes (25), representados bien por un solo ojo o bien con tres, y, algo menos, la de las tres Grayas (12)."

De manera que las Grayas de un solo ojo y un solo diente, con manos de cobre y que regalaran a Perseo un casco metálico mágico con el que se haría invisible, se referiría metafóricamente a que eran artesanas metalúrgicas, al igual que los Cíclopes.

En ambos casos, el tener un solo ojo aludiría, bien a que llevaban una diadema metálica con apéndice circular que caía sobre la frente, como un ojo / objeto circular de metal bruñido, que brillaría de día al reflejar los rayos del Sol. O portaban otro artilugio luminoso, una especie de lamparita con mecha y alimentada de sebo o aceite de oliva, que sería atado alrededor de la cabeza y brillaba en la oscuridad de la noche. Artilugio propio de mineros y metalúrgicos hasta hoy día. Y efectivamente, otros investigadores lo han interpretado así y dicen de los artesanos metalúrgicos que estaban: "Establecidos en la Tesalia (...), prácticos en metalurgia, trabajaron las minas en Samotracia (la ciudad de los kabires jinas), en Lemnos y en Macedonia, 
como hicieron los cíclopes del Peloponeso, Tracia, Asia Menor y Sicilia, los cuales penetraban en las entrañas de la tierra con una luz en la frente, luz que originó la fábula de que tenían un solo ojo." (Anónimo, 2004f).

Y confirma que Medusa, también era una artesana metalúrgica, porque las fuentes míticas nos lo informan, aunque de manera metafórica. Leemos: "Medusa tenía la lengua protuida, tenazas en vez de manos, serpientes en vez de cabellos, brazos largos y con la mirada lo convertía todo en piedra." (Carvajal, 2003). "De acuerdo con las descripciones y representaciones plásticas que han llegado hasta nosotros, Gorgona era un monstruo alado de garras afiladas, cuya espantosa cabeza tenía serpientes en lugar de cabellos, una lengua larga, unos dientes puntiagudos $\mathrm{y}$, sobre todo, una mirada penetrante que, según la leyenda, convertía a los hombres en piedra." (Anónimo, 2004b).

Cuando la describen como monstruo dañino con manos hechas de bronce, con garras afiladas, que usaba tenazas, tenía dientes puntiagudos, afilados colmillos de jabalí, quiere decir metafóricamente que fabricaba y usaba armas, quizás: hacha doble, o puñales, lanzas, arpones, o flechas que clavaba en sus enemigos al defenderse, al igual que los jabalíes usan sus colmillos para la defensa (no como los carnívoros, que usan los colmillos para atacar a sus presas). Y armas fabricadas con técnicas muy perfeccionadas, con aleaciones metálicas que permitía enviar flechas como rayos incendiarios, o quizás estaban impregnadas en venenos. Y cuando dice que convertía a la humanidad en piedra: lanzaría flechas abrasadoras que lo carbonizaba al alcanzado y lo convertía en sustancia mineral.

En todos los casos, es una idea simbólica que en realidad está codificando que sabía transformar por medio del calor los minerales en armas de bronce. Y lo haría en su taller de metalurgia, cuando los talleres estaban en manos femeninas. Y que fabricaba 
armas metálicas como: puñales, puntas de flechas, lanzas (colmillos de jabalí); objetos de protección y defensa como: cascos, escudos bruñidos circulares (= ojos) y corazas. Además objetos de adorno, que a la vez eran usados para defenderse, como: espejos circulares (= ojos en metales bruñidos), diademas con apéndices circulares que se ponían sobre a frente (= metáfora de Cíclopes), campanas y cascabeles. Objetos de trabajo agrícola para la labranza como: arados, arpones, tridentes... o para la ganadería. Utensilios para uso doméstico: vasijas, ollas... Y objetos religiosos como instrumentos musicales.

Recuerda el hecho de que eran artesanas metalúrgicas, las obras de arte que representan a las Gorgonas con señal en la frente, como las ilustradas en el Cuadro 4: serían un signo simplificado del apéndice circular que caía sobre la frente de los artesanos metalúrgicos, o del artilugio con llama que ardía de noche similar al que llevaban los Cíclopes.

\section{Cuadro 4}

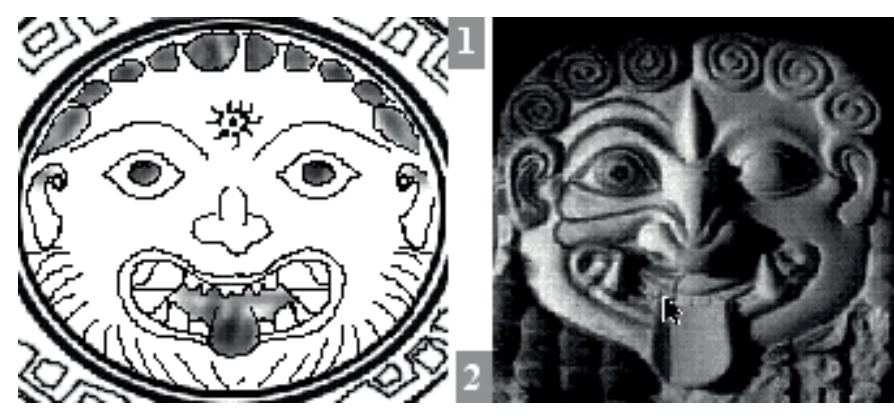

1: Medusa pintada en copa de Laconia, C. Taranto. Siglo VI adne

2: Medusa modelada en terracota en relieve del Templo de la Diosa Atenea Pallas de Siracusa 
La expresión de que la mirada de Medusa petrificaba a quienes la miraban, es similar a otros mitos de mujeres que tenían la capacidad de matar o esclavizar y hechizar con su mirada. Entre ellas: la Diosa / reina Semíramis, la Diosa Hubur, la cabeza de la Diosa Basilea "Reina", o las Bities / Bitgies Escitas del Cáucaso que según la E. U. I., Tomo 8 (1988, 994) eran: "Hechiceras famosas entre los escitas, las cuales, según Plinio, tenían la mirada tan fascinadora, que les bastaba fijar sus ojos, uno de los cuales tenía una doble pupila y el otro estaba marcado con una figura de un caballo, para matar ó hechizar a las gentes."

Y también se consideraba que castigaban, petrificaban y mataban con la mirada: las Diosa Juezas Furias que eran representadas de manera similar a las Gorgonas, con cabellos desgreñados (e incluso se muestra su equivalencia iconográfica corriendo y con alas en moneda de Arctonnesos, Figura 1 de Cuadro 3). Y el mito dice que castigaban a los criminales con la mirada, símbolo de que la reina-jueza que los juzgaba (bajo su advocación) en determinado día del año, los condenaba a morir abrasados en la hoguera o a arrojarlo a un horno, si lo encontraban culpable. Inspirándose para ese castigo en determinadas constelaciones cuando ocupaban determinada posición.

Y simplemente, el mito de los Cíclopes y de las Greas que tenían un solo ojo, o el mito de las Furias que castigaban con la mirada abrasadora, o el de las Hechiceras que mataban con su mirada, o el de la Gorgona que petrificaba, son metáforas que codificaban de forma enmascarada, que las artesanas metalúrgicas / Cíclopes, o las guardianas de Santuarios, o las juezas al servicio de Templos de Diosa, se defendían o castigaban de forma terrorífica con armas de fuego.

[En otros contextos, el Cíclope se referiría también a las altas torres con un espejo circular en la cúspide (torre con un espejo = gigante con un sólo ojo = Cíclope) o con 
un fuego que ardía de noche. Y Cíclope / torre situada en promontorios y lugares escarpados de ciudades marítimas, junto a Santuarios de Diosas.

Y Cíclope / torre con espejos usados de día para defenderse de navegantes invasores enemigos, cuyo ojo era la luz / el espejo bruñido y circular de bronce, como faro que reflejaba los rayos del Sol, que al ser dirigidos contra los barcos de los invasores / dragón vomitaba fuego, los achicharraría o los deslumbrarían. Gracias a ello les impedirían ver los peligros de la costa escarpada y naufragarían.

E igualmente el Cíclope / torre, en cuya cúspide se encendería fuego de noche, tendría entonces la función de faro / luz nocturna que ayudaría en la navegación (de manera paralela a la brillante estrella alfa / estrella fenicia de la constelación Dragón que ayudaba en la navegación)].

Así que, el verdadero sentido de que Perseo robase el único ojo y diente de las Greas, guardianas de las Gorgonas y que descabezase a la reina Medusa porque su mirada petrificaba y después utilizase su cabeza para petrificar a sus enemigos, estaría reflejando metafóricamente y de forma enmascarada, la apropiación patriarcal de los talleres y métodos para fabricar armas muy poderosas de pueblos matriarcales, en donde las metalúrgicas usaban armas metálicas con las que aterrorizaban a sus enemigos (que no poseían los avances técnicos para fabricarlos, por lo que se asombraban de su eficacia), así como de los Santuarios protegidos por torres de vigilancia / Cíclopes).

Lo corroboraría el hecho de que el mito narre que Perseo, para esquivar su mirada, se defiende con un escudo metálico pulimentado como un espejo, que devuelve su mirada al monstruo. Es decir, que se aprovecha de los avances de la metalurgia que conocía el pueblo que gobernaba la reina Medusa para construir en metal su escudo, 
que antes sería de cuero o madera blanda y frágil. Y tras adoptar las técnicas metalúrgicas más avanzadas para fabricarlo, construye un escudo bruñido, que antes fabricaba el pueblo matriarcal, y lo utiliza para matar a quien lo había inventado. Por ello, ella muere al verse en el espejo, es decir con la misma arma que ella había usado: talleres de metalurgia, defensa con espejos que deslumbraban...

Mostraría que la metalurgia del bronce estaría en principio en manos femeninas, el hecho de que muchos episodios de la belicosa historia de los primeros siglos del milenio II adne, consistía en la invasión por parte de pueblos patriarcales, de ciertas regiones matriarcales, atraídos por sus riquezas. La principal finalidad de la conquista era apropiarse de los centros de explotación minera cuprífera y de estaño y de los talleres de metalurgia existentes junto a los Santuarios de Diosas (servido exclusivamente por Sacerdotisas). Y en donde estaban además: los talleres de diferentes oficios artesanales, los de orfebrería del oro, los de acuñación de monedas / cecas, que en principio eran de carácter sagrado y estaban anexos a los Templos de Diosas y en donde guardaban el tesoro de la Diosa. Lo confirma M. Teresa G. Cortés (1993, 24): "... hay que exponer que en los templos erigidos a las diosas de la Vida aparecía la ligazón invariable de lo femenino con la riqueza y los objetos materiales, sobre todo cuando originariamente la fabricación de monedas tuvo lugar en los centros culturales de las diosas-madres."

El mito de que tras Perseo cortar la cabeza de Medusa, su cabeza pasó a decorar el escudo y la coraza Égida (arma defensiva y símbolo de Protección Divina) de la Diosa Atenea, indicaría que a partir de la revolución patriarcal, los mitos consideran que la Diosa Atenea se pone al servicio de los intereses guerreros del patriarcado, no como antes, que como Eirenóforos "Portadora de la Paz", defendía la paz y su símbolo era la corona de oliva. 
Y gracias al poder que les conferían los escudos y armas de bronce, los pueblos defensores del régimen patriarcal, con soldados implacables y héroes violentos que no amaban la paz, se pudieron seguir dedicando a invadir otros pueblos donde habitaban monstruos pacíficos y matriarcales: sus enemigos. $O$ sea que fue el conocimiento matriarcal de las técnicas de la metalurgia / la cabeza de Medusa que como espejo devolvía su propia imagen, que había aterrorizado a los pueblos patriarcales cuando estaban en manos femeninas, lo que sirvió para aterrorizarlas / vencerlas / ipara vencer al demonio!, cuando pasó a manos masculinas.

Y eso explica el porqué: "Ésta es la cabeza que aparece siempre en el escudo de Atenea; al parecer, la diosa la había recogido después de haber sido cortada por Perseo y la había colocado en la égida, porque conservaba sus prodigiosos efectos y constituía un arma poderosa contra el enemigo." (Anónimo, 2004b).

Y tal deducción es confirmada cuando dice J. M $\mathrm{M}^{\mathrm{a}}$ Aguirre en (2003): "Resulta interesante la confluencia de apoyos en la tarea de Perseo. El héroe no está solo, sino que toda una serie de fuerzas de las divinidades se ponen a su lado para ayudarle a realizar su objetivo. Tenemos dos elementos importantes: a) el escudo pulido que, sostenido por Atenea, sirve de espejo y devuelve la terrorífica y paralizante mirada de Medusa; y b) la invisibilidad de Perseo gracias al casco de Hades. Gracias a estos dos elementos, Perseo puede vencer a Medusa."

Si nos damos cuenta, Medusa no muere en combate a manos de Perseo, sino por el efecto mortal de su propia imagen. Al igual que los otros pueden ser víctimas de su mirada, Medusa muere al contemplarse en el espejo. El arma letal es ella misma." (....) 
"Resumiendo estos elementos, tenemos un hombre invisible que actúa sobre el monstruo femenino matándola con su propia imagen especular."

En otros episodios míticos, cuando se dice que Perseo petrificó a sus enemigos, el término sería usado en el sentido de inmovilizar / paralizar / derribar = castrar, que era el castigo reservado a los amantes de la Diosa (como el castigo sufrido por Pirito cuando trató de raptar a Perséfona). Y en ese sentido sería usado cuando Perseo petrificó a Fineo, antiguo pretendiente de Andrómeda, heredera legal del trono de Etiopía (hermano de su padre Cefeo y por tanto su tío): "En la boda de Perseo y Andrómeda, el tío de la novia, Fineo, armó un altercado de resultas del cual Perseo mostró la cabeza de Medusa y quedaron petrificados, además de Fineo, Abaris, Actiages, Agirte, Alciónides, Anfimedón, Anfix, Astreo, Atis, Celedón, Clito, Clitón, Cromis, Dano, Elis, Eriteo, Erix, Etemón, Etión, Flegias, Forfante, Hipseo, Lecabas, Molfeo, Nileo, Pétolo, Polidemón, Tésalo, Toactes..." (Juan José López, 2003).

Un sentido totalmente diferente se le da a petrificar cuando los mitólogos narran que: "Perseo utiliza la cabeza de Medusa para convertir a un horrible gigante en montaña ..." (Anónimo 20004e). Es una explicación mítica que se da como razón del porqué la montaña del Atlas tenía nubes en sus cumbres: el gigante Atlas, cansado de sostener el peso del cielo, le pide a Perseo que lo convierta en piedra.

La mirada petrificadora de Medusa ha sido interpretada con diferente sentido por otros investigadores, como: "El "mal de ojo", la envidia del vecino que te desea algún daño, y en los tiempos en que éramos animistas confundíamos la realidad con el deseo, por lo que si te deseaban algún mal, era como para echarse a temblar" (Juan José López, 2003). Igualmente: "Es también el ojo que fascina, que petrifica, lo que luego habría de convertirse en el Mal de Ojo." (Mercedes Aguirre, 2004). 
7. Sentido ritual de las imágenes de Medusa como máscara Gorgoneión con la risa en la boca y la lengua fuera

Hemos visto algunas imágenes artísticas de las Gorgonas de cuerpo entero y corriendo, de pueblos de la Edad del Bronce de la cuenca del Mediterráneo. Pero allí también abundan las imágenes de la cabeza sonriente y lengua fuera como máscara, identificadas con el llamado Gorgoneión. Algunos ejemplos los ilustramos en Cuadro 5 .

\section{Cuadro 5}
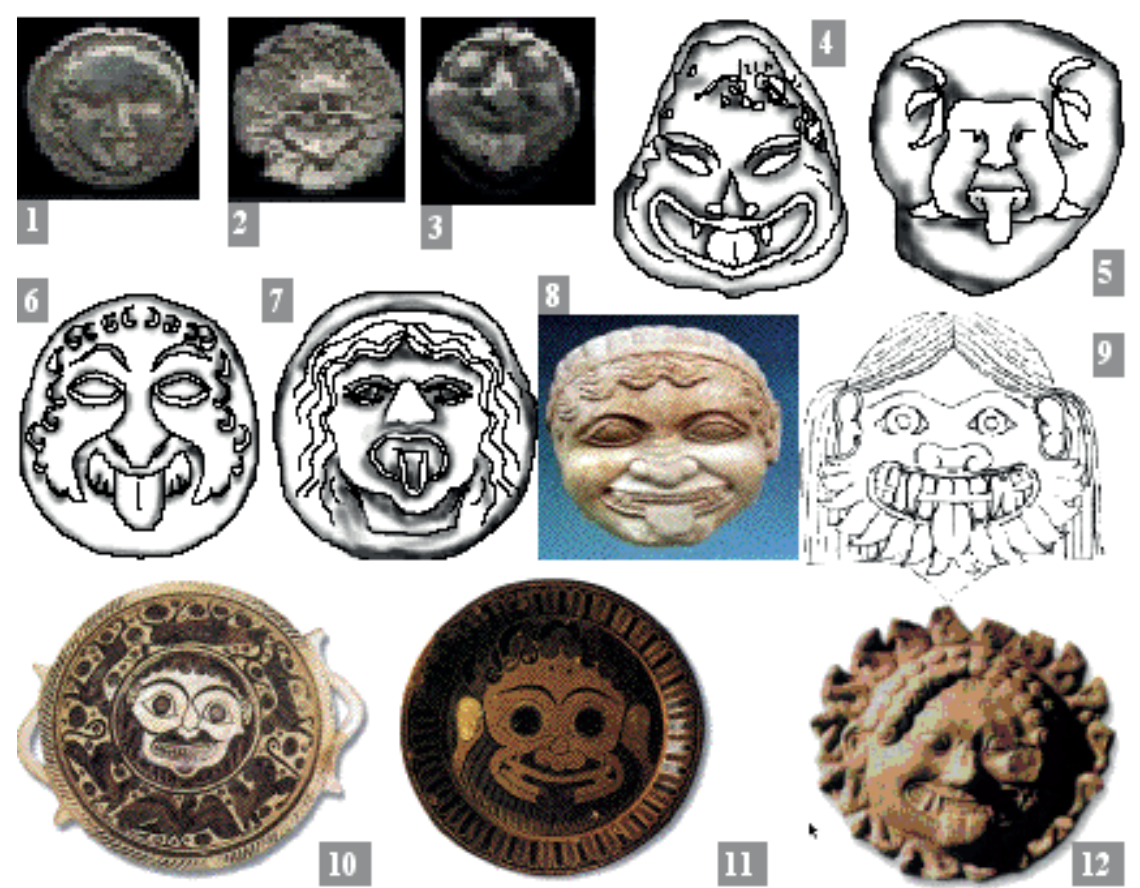

11

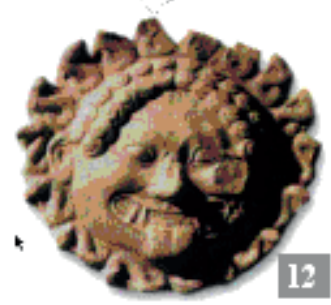


Imágenes artísticas de la cabeza aislada de la Gorgona Medusa del Mediterráneo, llamado Gorgoneión, sonriendo y con lengua fuera de la Edad del Bronce, algunas con cabellos rizados, otras con colmillos animalísticos... monedas de Antheia, Adrastea, Mitilena, Abydos, Eritras e Himae; esculturas de Atenas; platos de Madrid y Munich y antefija de Metaponto. Siglo VI adne. Invitarían a las Sacerdotisas a realizar actos orgiásticos determinados días de fiesta, para propiciar mágicamente que la Vagina de la Diosa enviase la lluvia, fenómeno benéfico para la agricultura y protegiese de los maléficos (y eso explica la "función apotropaica").

Se considera que el Gorgoneión, como máscara, tenía un sentido ritual, y era usado en ceremonias sagradas. Afirman los enciclopedistas al respecto: "... y aunque no consta en documento alguno, es de creer que bailaban con él a modo de máscara, en las danzas rituales."(...) "El nombre Gorgoneion presupone, es verdad, la Gorgona, pero la concepción ó idea del monstruo nació de la cabeza sin tronco, ó de la máscara.» (J. E. Harrinson...)" (E. U. I. Tomo 26, 1988, 709).

Y añaden: "Hoy es cosa sabida que Las Gorgonas no deben su origen a la mitología, sino al ritual, y que eran expresión ó (sic) símbolo de una emoción religiosa muy primitiva." (...) "Lo que los griegos hicieron, como también en otros asuntos, fue (sic) dar rienda suelta á (sic) su fantasía disimulando un hecho sencillo, el empleo de máscaras rituales para fines mágicos y especialmente apotrópicos. La Gorgona como monstruo nació del Gorgoneion "la cabeza ó cara espantablis; no el Gorgoneion de la Gorgona.» (J. E. Harrinson..."

Más tarde, con la evolución patriarcal y las representaciones de comedias griegas exclusivamente por varones, se siguió usando el Gorgoneión como máscara de comedia / de teatro, y se separó en una máscara cómica, con la boca sonriente y otra trágica, con una mueca triste. Y ello explica el porqué: "tenían cara femenina 
sonriente y burlona y lengua fuera" (cita de enciclopedistas a Fay Cooper Cole de 1913, E. U. I., Tomo 26, 1993: 709). Y así era representada en monedas de Mitilena, de Himae... Cuadro 1.

Gorgoneión que las Sacerdotisas usarían en festivales Mistéricos trágico-cómicos de la religión pagana "agrícola", que en principio era propio de mujeres, celebradas en tiempo de arado y siembra, consistentes en a) hierodramas sagrados trágicos (origen de las comedias) y en b) actos cómicos mágicos secretos (cuyo sentido original sólo se transmitía a las iniciadas).

a) En los hierodramas sagrados, se representaban y desarrollaban los episodios trágicos en relación con la plantación de la semilla (muerte) y su germinación. Eran expresión de una leyenda que celebraban las penas y posterior alegría de una Diosa Salvadora, Diosa de la Agricultura, por la muerte de su paredro (semilla) y su resurrección (germinación).

b) En los actos cómicos secretos, las participantes realizaban orgías / masturbaciones (llegaron a saberse porque las practicantes de los Misterios de la Buena Diosa fueron expiadas mientras celebraban sus rituales sagrados orgiásticos (masturbaciones colectivas tanto a solas como unas a otras), según contaba Juvenal en (1982, 53). Y añadía en $(1982,93)$ : "... estas Ménades de Príapo (falóforas que llevarían atados un falo artificial) se salen fuera de sí y agitan las cabelleras. ¡Oh, qué ardor se apodera de su espíritu! Qué gritos en sus retozos! ¡Cómo resbala en torrentes el viejo vino a lo largo de sus mojadas piernas!", con finalidad mágica. Servían para propiciar los fenómenos (lluvias) de los que dependía la cosecha de las plantas y asegurar la Fertilidad de la Naturaleza. 
No tenemos ninguna representación artística del ritual orgiástico de los festivales Mistéricos, pero tenemos una escultura del siglo XVII de una Sacerdotisa Bilian de Diosa Rangda de Bali, Indonesia Cuadro 6.

\section{Cuadro 6}

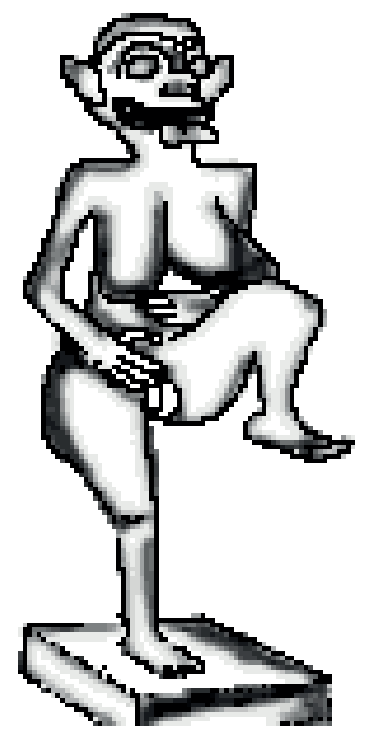

Escultura de madera de Sacerdotisa Bilian de Diosa Rangda que se masturba con la mano, mientras porta máscara animalística sonriente y lengua fuera, único testimonio iconográfico que conocemos que representa crudamente la masturbación sagrada, de Balí, Indonesia.

Al hacer que su vagina derramase líquido, pretendería propiciar mágicamente que la Vagina de la Diosa enviase la lluvia (y la máscara animalística aludiría al aspecto Divino.

Dado que la mujer se masturba, mientras lleva una máscara animalística con boca sonriente y lengua fuera, esta escultura daría la clave y acreditaría la asociación entre la orgía femenina y el gesto de sacar la lengua de las obras de arte de la Edad del Bronce del Mediterráneo. 
Aunque es de una región y cultura muy alejada del Mediterráneo, es otro ejemplo más de la universalidad de los mitos, los rituales, la religión, el arte que desde la Prehistoria se transmitieron a todos los confines, argumento que ha hecho afirmar a los investigadores: "Es muy probable que los misterios de los grandes dioses hayan tenido el mismo origen y seguido idéntico proceso evolutivo" (E. U. I., T. 35, 1988: 1031).

Si el ritual orgiástico ancestral permaneció y se conservó por más tiempo en Indonesia, es porque allí las tradiciones matriarcales no serían censuradas, razón de que un artista se permitiera reflejarlas y la orgía dejara de ser secreta.

Por lo que deducimos que, las imágenes femeninas sonrientes con la lengua fuera de la cuenca del Mediterráneo de la Edad del Bronce, serían modelos para rituales masturbatorios.

El sacar la lengua y el reírse, considerado en occidente como un gesto de burla o de mofa, tendría en el ritual orgiástico arcaico una función triple.

1. Por un lado, igualmente recordaría a las practicantes que "soltasen la lengua" y riesen, es decir, que recitaran groserías y obscenidades de carácter religioso y se burlaran unas de otras (como se hacían con los himnos de las representaciones burlescas de los Gefirismos, Stenia... en los que se decían palabras soeces y zumbas picantes). (Así que no extraña que sacar la lengua terminase por confundirse con el gesto de burla y zumba).

2. Por otro lado, el gesto de sacar la lengua durante la orgía sagrada, facilitaría a la mujer para que se abriese, se rajase, empezara a romperse y con ello favoreciese la producción de secreción vaginal (símbolo funcional de lluvia). 
3. Y además sería un acto impúdico de ofrecimiento al cunnilingus, para aumentar la secreción vaginal, en la relación orgiástico-lésbica.

Si se realizaba tal acto como sagrado sería porque se concedía al acto de segregar lubricación del orificio vaginal, simbología mágica para hacer llover. Con la masturbación, con las manos o con esculturas fálicas o con la lengua, de las representantes de la Madre Naturaleza, le suplicarían / conminarían / exigirían que de su Vagina Divina segregase líquido / agua de lluvia (fenómeno benéfico par la vegetación y los frutos) por magia mimética. Es decir que la Diosa enlutada, triste por la muerte de su paredro (semilla enterrada), rompiese a reír y a llorar, para que mágicamente la lluvia regase los campos donde se encontraban enterrados las semillas muertas.

O sea que, resumiendo: las Sacerdotisas utilizarían las máscaras Gorgoneión con la risa en la boca y la lengua fuera en ceremonias sagradas orgiásticas, para propiciar que la Diosa enviara la lluvia, tras el arado y sembrado de los campos de cultivo y así hubiese abundante cosecha. Y lo harían cuando la faceta animalística de la Diosa así lo indicaba / cuando la constelación Cabeza de Medusa ocupaba determinada situación en el horizonte, anunciadora de las lluvias benéficas para la Fertilidad de la vegetación. Por lo que las Sacerdotisas, que eran expertas conocedoras del calendario y de la astronomía y que habían observado tales coincidencias, llevaban a cabo sus rituales de provocación de este fenómeno, cuando sabían estadísticamente que era el momento en que la "Diosa les iba a echar cuenta".

\section{Imágenes con la risa en la boca y la lengua fuera, identificadas con Diosas o sus Sacerdotisas}

a) Hembras animalísticas e híbridas con la lengua fuera desde el Paleolítico 
No sólo estas imágenes artísticas de la Edad del Bronce muestran la lengua fuera. Nuestros ancestros nos han legado desde el Paleolítico otras representaciones con la sonrisa y la lengua fuera de figuras: de mujeres, de animales y de antropozoomorfas / híbridas. Y deducimos que tendrían la misma finalidad de propiciar a la Divinidad para que enviara las lluvias benéficas para la Fertilidad de la vegetación. (Si no aparecen obras de arte de animal macho o de varón con tales características contemporáneas, es porque no hemos encontrado ninguna. Sólo se adoraba a la Madre Naturaleza. Después de la Edad del Bonce, acorde con el politeísmo, aparecen de animales).

Presentamos en el Cuadro 7 algunos ejemplos animalísticos y antropozoomorfos realizados: en el Paleolítico europeo (1), en la Edad del Bronce de Europa $(2,6,7)$ y Asia $(3,4,5)$, y en la Prehistoria americana $(8,9,10)$.

\section{Cuadro 7}

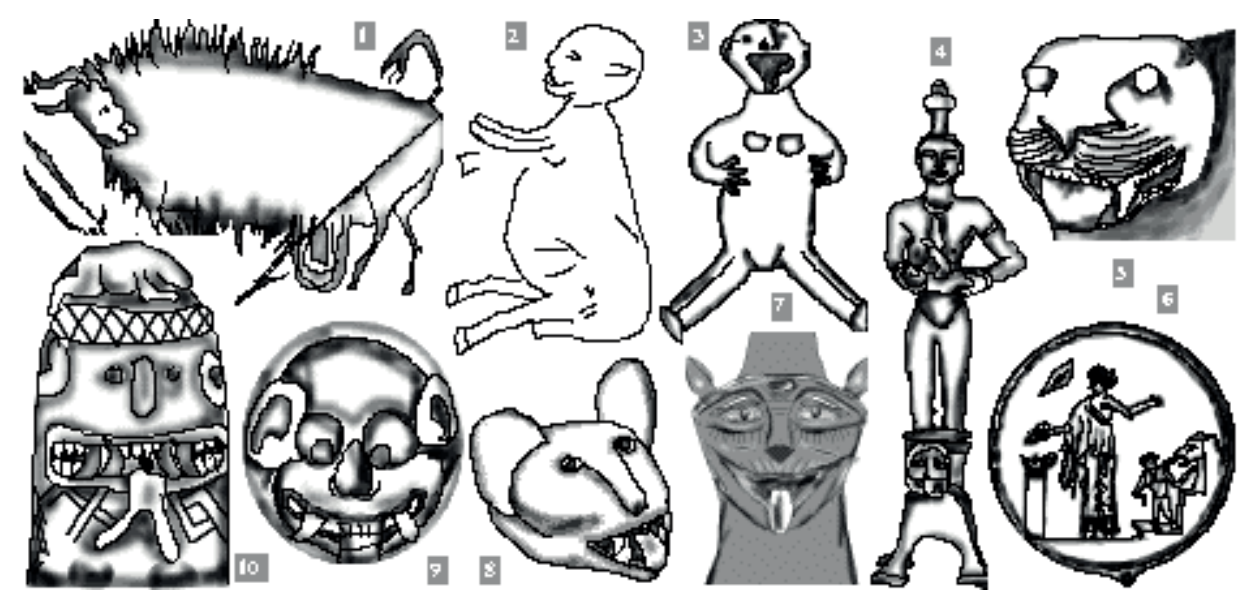

Imágenes artísticas de animales y antropozoomorfos sonriendo y con lengua fuera, representaciones de Diosas con máscaras animalísticas 
1: Pintura de bisonta-Diosa con lengua fuera, flecha clavada y bolsa matricial rota, Santuario de Lascaux, Francia

2: Pintura de antropozoomorfa-Diosa embarazada con lengua fuera de Saint Cirq, Périgord, Francia (de la que sería heredera la Diosa Artio "Osa")

3: Vasija antropozoomorfa con cabeza de osa con lengua fuera que hace de vertedor, representación de la Diosa Osa Brauronia. Cultura Escita de Marlik, cerca del mar Caspio

4: Diosa Hebat amamantado a su bebé, encima de leona con lengua fuera, en bronce. Cultura Hitita de Anatolia

5: Cabeza de leona con lengua fuera, en piedra, representación de la Diosa Hebat o Sausga. Cultura Hitita de Karatepe, Anatolia

6: Moneda de Sacerdotisa de la Diosa Himera quemando incienso y provocando humo junto a gárgola de leona-Diosa que mana agua, de Himera, Sicilia

7: Vasija con cabeza de leona-Diosa, con lengua fuera que hace de vertedor y con líneas paralelas bajo ojos como torrentes de lágrimas, de bronce. Cultura Tartésica de Niebla, Huelva, España

8: Cabeza de felino con lengua fuera, de oro, plata y cobre, con colmillos de concha y ojos de piedra, que representaría a la Diosa Ix Balam Qué Diosa tigre joven, de la Luna nueva y del Maíz tierno. Cultura Mochica, Perú 
9: Disco de Ahuachapán con colmillos de felino y lengua fuera, representación a la Diosa Comizahual, México

10: Monolito de Diosa con cabeza y colmillos de felino y lengua fuera bífida, de piedra, de Nicaragua

b) Otras figuras femeninas con lengua fuera

Y en el Cuadro 8 mostramos otros ejemplos de seres humanos femeninos con lengua fuera y caracteres animalísticos como colmillos.

\section{Cuadro 8}
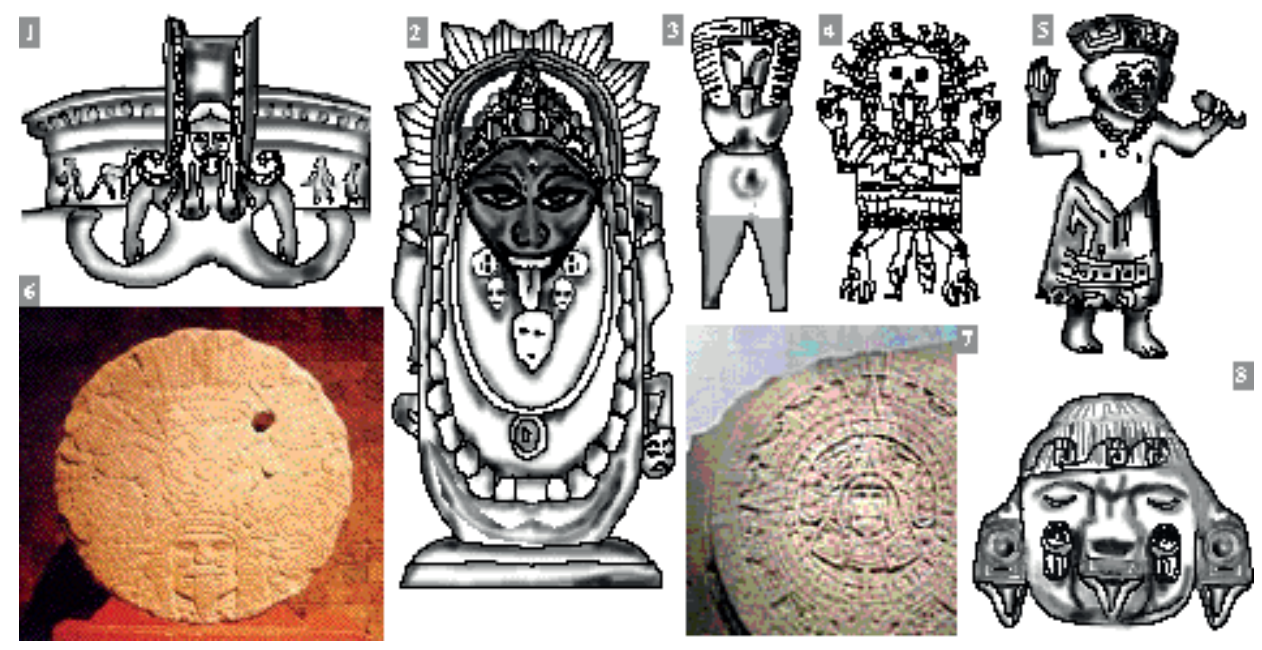


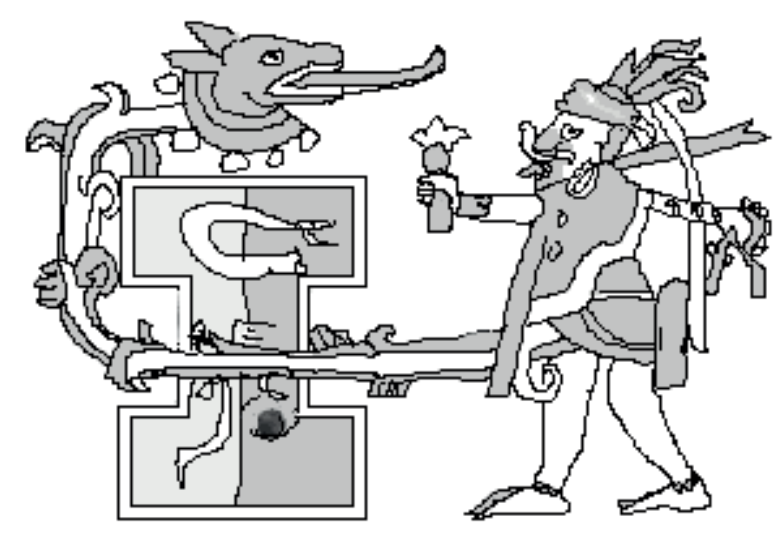

Imágenes artísticas de Sacerdotisas y Diosas sonriendo y con lengua fuera

1: Crátera de bronce de Vix, Galia decorada con "Gorgona" con lengua fuera, además con cabellos de trenzas-espigas-serpientes

2: Escultura de Diosa Kali con lengua fuera y señal en la frente, La India (a la que se le cantaban canciones obscenas para aplacarla ¿y así propiciar la lluvia?)

3: "Venus de Valdivia" con lengua fuera, Ecuador, cuyos rasgos de la cabeza recuerda los de una felina

4: Dibujo de Diosa Tzitzimime con lengua fuera pintada en el Códice Magliabecchiano, México, además con serpientes saliendo de su vulva

5: Escultura femenina de cultura de Veracruz con lengua fuera, Remojadas, México, además con líneas paralelas bajo ojos como torrentes de lágrimas y un objeto ¿fálico? en la mano izquierda ¿está invitando a la masturbación para propiciar lluvia?

6 y 7: Relieves aztecas en forma de disco con cara de Diosa Tierra Tlaltecuhtl con lengua fuera, con tocado azteca en forma de casco con adornos colgantes a los lados 
en las orejas (y que es exclusivo de las mujeres) de México (la segunda: "la Piedra del Sol o Calendario azteca, enorme bloque circular trabajado en relieve y dedicado a la divinidad solar Tonatiuh que algunos investigadores atribuyen al monstruo de la tierra Tlaltecuhtli": Panero, 2005). Datados entre los años 1250-1521 dne

8: Cabeza de Diosa Coyolxauhqui "Adornada de Cascabeles" / "Adornada de Frutos de Palma" con lengua fuera, tocada con casco y con cascabeles o frutas en las mejillas. Museo Nacional de Antropología de México

9. Diosa con lengua fuera, pintada en página del Códice Fejervary-Mayer, de cuya vulva sale metafóricamente un largo cuello, que atraviesa un aparato y acaba en una cabeza animalística, también con lengua fuera

Las imágenes artísticas de época histórica de mujeres o antropozoomorfas hembras con lengua fuera, según lo explicitan las fuentes, son bien representaciones de Diosas con sus máscaras animalísticas con nombres conocidos, o bien representan a Sacerdotisas, vicarias de la Diosa. Pero también las imágenes de hembras animalísticas o de antropozoomorfas de diferentes especies, tanto del Paleolítico como de culturas prehistóricas, serían representaciones de la Diosa, según se deduce de lo afirmado por numerosos investigadores.

Y así Nadal, explicita que las imágenes de leonas paleolíticas se identificarían con la Diosa, cuando afirma en (1999): "La relación de la diosa madre con las leonas parece comprobado que existe desde el Paleolítico: cueva de Les Trois Frères, en la Dordoña francesa, entre 18000 y 14000 a.C.; también en el templo de la cueva francesa de Pech Merle, con la forma de una insólita figura roja conocida como la reina león; en lo alto de Yazilikaya, capital de los hititas, la imagen espectacular de la diosa madre de Anatolia de más de dos metros de altura." 
Asimismo otros autores generalizan la identificación del animal reflejado en una obra arte paleolítica, con una Diosa: "En el gran santuario de Lascaux, lleno de cámaras que se ha llamado «la Capilla Sixtina del paleolítico»- se ha hecho manifiesta una experiencia de la divinidad, no como en Chartes o en el Vaticano en figuraciones humanas (antropomórficas), sino en animales (teromórficas)." (Campbell, 1991: 342) y "la Diosa es la única divinidad visualizada en aquel entonces." (Campbell, 1991a: 242). También las representaciones de animales rupestres del arte paleolítico cantábrico representaría a la única Diosa adorada en principio. A propósito de ello comenta Andrés Ortiz-Osés (1982, 32): "Barandarián llega a apuntar ciertas correlaciones entre la Diosa y las figuraciones animales rupestres."

Jacques Pirenne aporta que tal identificación animal-Diosa ha sido universal en (1982, 39): "Probablemente la misma evolución se operó entre todos los pueblos, pues, cosa curiosa, todos han dado a la diosa madre los mismos atributos ... ella es la vaca, la leona, la gata;..."

Westheim constata la misma identificación animal-Diosa para los felinos hembras de la Prehistoria americana, cuando afirma en $(1988,101)$ : (para los Mayas) "el jaguar es el animal del cielo nocturno, de las Diosas Lunas; la anciana Diosa de la Luna está a menudo representada con garras de jaguar". Y Girard, Tomo II corrobora en (1978, 398): "... el culto al jaguar está omnipresente en la América Central. Representaciones de felinos... están asociadas al culto de la Luna, Diosa Madre, y de la Fertilidad, una deidad cimera de las sociedades femeninas". Y añade: "La asociación luna-jaguar se expresa en forma grandiosamente sintética en el disco de Ahuachapán (nuestro Dibujo) que representa la Diosa lunar en su forma astral, con un rostro humano cercado de colmillos de tigre (...). Da la impresión de una figura chavinesca y evoca 
el mito de (la Diosa) Comizahual, el tigre que vuela; y era una "señora blanca, como la luna "y estos indios estimaban mucho al tigre." (Fran Juan de Torquemada...)".

Por lo que deducimos que la figura paleolítica con caracteres de osa de Saint podría ser el antecedente de la Diosa histórica adorada en la misma región y que es conocida como Diosa Artio "Osa" (Markale, 1989: 133); la osa de la vasija Escita sería antecedente de la histórica Diosa Osa llamada Brauronia; la leona sería el animal simbólico y atributo de cualquiera de las Diosas leonas históricas adoradas en amplias regiones del Mediterráneo: Artemisa, Anahita, Hebe / Hebat, Sausga, Cibeles, Atargatis, Mitra, Nanaya, Urania... Y las felinas de culturas de América (jaguar, tigre, ocelotl, puma) representarían a otras Diosas: bien la adorada por peruanos en forma de tigre llamada Ix Balam Qué o la adorada por mexicanos llamada Comizahual.

Por lo que las representaciones artísticas con lengua fuera, intentarían propiciar al aspecto animalístico de la Madre Naturaleza, que cuando personificaba determinada constelación y ocupaba determinada posición, enviaba las lluvias coincidentes (en este caso cuando se producía el ocaso verpertino de la constelación Cabeza de Medusa se esperaban las lluvias, gracias a las cuales, se producía días más tarde la floración de la primavera. Y situación estelar que tenía lugar hace 5.300 años, el atardecer del 14 de febrero).

\section{La risa orgiástica de Sacerdotisas, para hacer llover y germinar la semilla, también modelo de la risa orgiástica de Sacerdotes cristianos, para resucitar a Jesús}

Estos cultos sagrados de Sacerdotisas paganas (de religiones "agrícolas") que se reían, decían palabras soeces y masturbaban durante las fiestas trágico-cómicas en tiempo 
de siembra de semillas, fueron heredados por el ritual cristiano del Risus paschalis "Risa de Pascua".

El ritual consistía exactamente en que los oficiantes cristianos en el recinto de las iglesias durante la Pascua, se subían los ropajes, mostraban los genitales y se masturbaban ante los fieles, lo que provocaba sus risas. Además decían: "palabras y cantos obscenos pronunciados por el sacerdote desde el año 852 y, (...) documentada en varias formas y en múltiples lugares, a través de un larguísimo espacio de tiempo." (Jacobelli, 1991: 73). De ahí el dicho de que la Cuaresma "empieza con la ceniza y acaba con la risa" (Benjamín Hernández, 2004).

Estos rituales tenían lugar durante las fiestas de Resurrección de la Semana Santa, fiesta que celebra la muerte y resurrección de Jesús.

Aunque los mitólogos cristianos consideren a Jesús como un ser humano, es obvio que existe una disonancia entre su existencia humana y la metáfora agrícola que implica que Jesús sea el "fruto" del bendito vientre de la Virgen (Madre Árbol), que muere para "dar de comer" a la humanidad. Por lo que en realidad, el mito de Jesús imita a los de otros paredros de la Diosa de otras religiones, cuya vida narra la historia de la agricultura.

1. Lo confirma por un lado, porque el mito diga metafóricamente que nace en Belén / Bethlehem / Efrata "Casa del Pan". O sea que Jesús nace como espiga de cereal / "fruto" que es transformado en harina, y con la que se elabora el pan tras recibir fuego en un horno.

2. Por otro lado, porque según el mitólogo (Mat, 26, 26), dice metafóricamente al repartir el "pan" a sus discípulos: "Tomad y comed, éste es mi cuerpo". 
3. Además, el mito sigue diciendo metafóricamente, que Jesús moría como semilla que se enterraba para germinar / resucitar como vegetación en la primavera (en la fiesta de Resurrección de la Semana Santa).

Así que no extraña, que los Sacerdotes, vicarios del Dios patriarcal, se masturbasen y ríesen con la finalidad de que su falo derramase líquido, y así propiciar mágicamente que el Falo Divino derramase mágicamente abundantes lluvias para que la semilla germinara / Jesús resucitara (al igual las mujeres se masturbaban y reían con sus dos sonrisas (horizontal y vertical) para que su vagina derramase líquido, y así propiciar mágicamente que la Vagina de la Madre Naturaleza se abriese y ríese y enviase la lluvia que haría germinar la semilla en tiempo de siembra de la primavera).

En la nueva mitología patriarcal, los vicarios del Dios cristiano, celebraban en honor de un Dios el mismo ritual que anteriormente se practicaba en honor de una Diosa Hermafrodita. E imitaban a las representantes vicarias de la Madre Naturaleza de religiones paganas "agrícolas" matriarcales del Próximo y Medio Oriente, las Sacerdotisas: Isíacas, Ciniradas, Heteras, Crétidas, Dicteríadas, Delíadas, Saces, Basáridas / Eleleidas, Clodonas, Canéforas, Falóforas, Cordasianas, Colias, Damiatrix, Hilarodas, Coras, Edónidas, Mimalonas, Médicas Esfragítidas, Bacantes, Citeríadas, Cariátides, Baptas, Meliastas, Dionisiadas...

Si la iglesia cristiana mantuvo durante cientos de años en toda Europa hasta el siglo XIX, de una manera directa y sin disimular, los actos orgiásticos a imitación de los de las antiguas Sacerdotisas, es que hubo un tiempo en que conservaron la creencia de que la sexualidad era sagrada y debían conocer la metáfora que fundamentaba el rito de la masturbación: para hacer llover (aunque las mitólogas matriarcales mantuvieran en secreto su doctrina, debió pasar a sus imitadores). 


\section{Mujeres del siglo XX reivindican la liberación a través de la risa asociada al placer sexual y el derecho a ser obscenas}

Estas prácticas de los Sacerdotes durante el ritual cristiano del Risus paschalis "Risa de Pascua" (y otras conductas sexuales), convivían de forma inconsistente con la exigencia de celibato de los: "párrocos, profesión que conllevaba otros menesteres y actividades, algunos lejos de la moralidad que propugnaban." (Hernández, 2004). Y también coexistían con el código moral que reprimía fuertemente la sexualidad de los fieles, especialmente de las mujeres (poniendo de manifiesto la ley del doble rasero).

Hechos que muestran cómo los jerarcas de la doctrina cristiana han sido capaces de conjugar ideas contrarias, mientras no han sido cuestionadas (y ha debido ser muy fuerte la presión para que haya desaparecido totalmente las prácticas sacerdotales de la "Risa de Pascua", mientras que las relaciones heterosexuales y homosexuales del clero, nunca han decaído. Y la presión aún debe haber sido menor sobre las conductas sexuales delictivas de algunos misioneros violadores de monjas en sociedades primitivas, o las de Sacerdotes paidófilos en culturas occidentales, puesto que siguen persistiendo impunes, a pesar de haber sido denunciadas repetidamente).

Afortunadamente, y al contrario de lo que ha ocurrido en las sociedades islámicas, en los Estados de las sociedades cristianas occidentales, surgieron las condiciones para que, con el tiempo y la democracia, las mujeres se incorporaran a la vida activa y a la cultura. Con lo que se les allanó el camino para que se concienciaran de su subordinación y de su limitación sexual.

Desde entonces, las feministas: psicólogas, antropólogas, poetisas y demás intelectuales, han buscado y analizado la causa de que tales cosas sucedieran. 
Y al buscar las evidencias que testificaban cómo se les había impuesto la subordinación y la tiranía de la represión sexual durante los últimos miles de años, encontraron las conexiones culturales de las mismas con los mitos griegos que concretizaban el código ético y la visión patriarcal, en los que se fundó la civilización occidental hace 2.500 años.

Desde su descubrimiento, no han parado de cuestionarlos y de buscar los medios de definir una nueva identidad genérica que les ayudase a salir de su subordinación y alcanzar la libertad. En su búsqueda han tropezado con una de las estrategias para ello: "la deconstrucción de los mitos y figuras constitutivas de nuestra tradición occidental" (J. Ma Aguirre, 2004).

Algunas feministas han encontrado la ocasión de revindicar una nueva identidad, por ejemplo, a través del mito de revalorizar a la sonriente Gorgona Medusa que fue descabezada por el defensor de la cultura patriarcal Perseo.

Y para no dejarse manipular ya más por la ideología patriarcal, propugnan parecerse a las Gorgonas y a Medusa y que los varones dejen de ser "Perseos" que se horroricen ante la injusticia contra las mujeres, no ante la sexualidad libre femenina.

Animan a las mujeres a tener, como las Gorgonas, la lengua suelta para expresar opiniones, o para decir palabras soeces y obscenas, a reír con sus sonrisas: vertical y horizontal, para darse placer a sí mismas, o a sus compañeras de género, o a varones complacientes que las hagan reír de todas las formas posibles.

A que tengan la mirada centelleante y luchen y se defiendan con sus ojos, como armas hirientes que enamoren cuando quieran y deseen. Y también a que usen las 
armas de fuego, necesarias para defenderse con centellas, que achicharren cuando sean atacadas.

A que rían y disfruten del placer sexual sin que ningún Perseo machista y vengativo se sienta amenazado en su virilidad por ello, y no se atreva a cortarle la cabeza / le limite el derecho a soltar la lengua y reír cuanto quiera. Ni que haya "virginales Ateneas" que se ofendan por la sexualidad de Medusa (que otras mujeres introyecten y encarnen los valores patriarcales, reincidiendo en la desigualdad de los géneros).

Un ejemplo de feminista que ha encontrado el camino para la liberación de las mujeres a través de la risa asociada al placer sexual, es Cristina Escobar, que expresaba su deseo de reír más a menudo con sus dos sonrisas. Y decía en (2004): "Sé que es un desperdicio que en estos tiempos no utilizo mi sonrisa vertical. (...) En mi vida siempre ha existido una conexión muy fuerte entre esas dos sonrisas. Ambas se abren cuando se divierten, las dos son más expresivas y sinceras cuando se enamoran, las dos suelen ser influenciadas por la marihuana, ya sea por ataques de risa que nunca acaban o por ganas de tener sexo sin final. (...) Cuando hago el amor, aparece esa sonrisa de niña en mis labios, esa sonrisa fresca y verdadera."

Y como un acto de reivindicación para conseguir la liberación sexual de las mujeres de próximas generaciones, otras feministas como Betty Dodson, Nancy Friday, Lonnie Barbach, Jocelyn Elders... promueven enseñar a «cantar y a reír» / «estimular la sexualidad a las niñas» desde que son pequeñas, para que cuando sean adultas, se conviertan en impúdicas, lascivas y liberadas mujeres, que sonrían cuánto y cuándo quieran. Que se les inculque el abandono del modelo de virtud, de decencia y de moderación verbal, para que tengan como las Gorgonas, la lengua suelta y expresen libremente sus opiniones, digan palabras soeces y obscenas. Estímulo de la sexualidad de las niñas que han venido haciendo las madres de tribus matrilineales 
oceánicas y africanas a sus hijas (al menos hasta que llegaron los misioneros cristianos), gracias a lo cual han disfrutado de gran autonomía y poder.

Así, la poetisa Tina Suárez, reivindica el derecho de las niñas a que abandonen la imposición patriarcal y los preceptos de sus doctrinas, para que dejen de ser "enfermas de silencio". Y critica abiertamente a los psicólogos defensores de la represión de la sexualidad de la infancia, sobre todo de las niñas. Causa de que presente (a las niñas vengándose) con la: "sonrisa adversa clavándole alfileres a la foto de piaget" (Poema Rara Avis de su libro: Huellas de Gorgona (1996), aportado por J. Ma Aguirre, 2004). Incorpora la reivindicación de la risa femenina asociada al placer sexual de la infancia y propone que las niñas sean "escasas de buenos modales" e "insolente de la risa". Porque: "Gorgonas son las niñas malas, aquellas que se distancian de las normas establecidas; gorgonas son las niñas ridiculizadas por ser diferentes; gorgonas son las que se niegan al amor tópico, a ser románticas sentimentaloides, las que se niegan a seducir con parpadeos; gorgonas, en fin, son las que buscan su camino traspasando esa línea imaginaria de lo aceptado y lo conveniente." (Mismo poema de Tina Suárez, 1996).

Tina elige como introducción a su poema unas palabras de Lorca: "y yo oigo el canto de la lombriz en el corazón de muchas niñas" con las que usa la metáfora de cantar también asociada al placer sexual (de la masturbación, de las relaciones promiscuas y bisexuales: homosexuales y heterosexuales). Y cantar y reír como hacía la poetisa ateniense Datis: "... que cantaba una vez a mediodía mientras se frotaba: « ¿Cómo me gusta y me complazco y me divierto!»." (Aristófanes, 1990: 131).

J. Ma Aguirre reflexionaba en (2003): "Mi interés aquí es tratar de explicar por qué en ciertas autoras literarias, poetas, para ser más precisos, se ha retomado la figura de una Gorgona, Medusa, en concreto, para reivindicar la nueva condición del sujeto 
femenino. Este caso debe incluirse entre aquellos otros intentos que, desde distintos frentes artísticos, se han propuesto para realizar un desenmascaramiento de los mecanismos culturales. Es decir, aquello que apuntamos anteriormente: cómo los elementos culturales, especialmente los simbólicos por excelencia, son portadores, en este caso, del patriarcado o de su cultura."

Y añade: "El que las mujeres abandonen el papel que los hombres tradicionalmente les han asignado y se dirijan hasta el extremo contrario debe ser analizado con cierto detalle. Cuando se asume la posición de Medusa se está produciendo un rechazo de la construcción poética tradicional de lo femenino en la medida en que se entiende como falsa, es decir, una posición que no representa a la mujer, sino la idealización que los hombres han realizado para ellas."

Y efectivamente, las poetisas feministas con su capacidad abstractiva y de síntesis proponen un modelo opuesto al machista de "Perseos" descabezadores y amordazadores: ellas estimulan y potencian la lascivia y la impudicia femenina para que alcancen la libertad y la independencia.

Otras feministas aspiran a que las mujeres abandonen el reírles las gracias a los varones machistas que las denigran, y que dejen de estar sometidas y a su servicio sexual, ya que cuando les ríen las humillaciones, en realidad tienen los: "labios entrabiertos en la sonrisa complaciente fuera de lugar equivalen, simbólicamente, a una vulva que se ofrece." (Giberti, 2004).

\section{Bibliografía}


AGUIRRE, J. Ma . (2003): La mujer descabezada. Representaciones de la Gorgona en la poesía de mujeres: Tina Suárez Rojas.

http:/ / www.ucm.es/info/especulo/numero24/gorgona.html

AGUIRRE Castro, Mercedes. (2004): Las Gorgonas en el Mediterráneo occidental. Revista de Arqueología 207, Julio 1998.

http://www.ucm.es/info/seic/online/gorgonas.htm

ALCINA, J. (1982): Arte y antropología. Alianza Editorial, Madrid.

ANÓNIMO. (1984): Le Art des Cavernes. Atlas Archèologiques de la France. Ministêre de la Culture, París. (De este libro tomamos como modelo para nuestro dibujo de Saint Cirq la foto de G. Delluc).

ANÓNIMO. (2004a): Algunas monedas de la Antigua Grecia.

http://www.tesorillo.com/grecia/griegas.htm

ANÓNIMO. (2004b): Gorgonas.

http:/ / es.geocities.com/tematika2003/gorgonas.htm

ANÓNIMO. (2004c):

http://www.dearqueologia.com/presentacion.htm

ANÓNIMO. (2004d):

http://www.ancientgr.com/Unknown_Hellenic_History/images/Medoyses.jpg 
ANÓNIMO (2004e): Mitología griega. Medusa. Eros. Tántalo. Marte. Afrodita. Mircea Eleades. Zeus. Poseidón. Orígen mitológico del mundo. Inframundo. Héroes. Oráculos. El Rincón del Vago S.L.

http://html.rincondelvago.com/mitologia-griega.html

ANÓNIMO (2004f): Capítulo XXVII. Arios y "jinas".

http://www.samaelgnosis.net/libro/html/libro_jinas/capitulo_27.htm

ANÓNIMO (2004g): Panteón Griego.

http://espanol.geocities.com/bos_nimue/grecia.html

ANÓNIMO: (2005): Coyolxauhqui.

http://www.jornada.unam.mx/2003/abr03/030402/tradicion.html

ARISTÓFANES. (Traducción de Francisco Rodríguez Adrados). (1990): La Paz. Ediciones Cátedra, Madrid.

ATIENZA, J. G. (1991): La Religión de la Tierra. Integral, No 136, Volumen 4, abril, Barcelona.

BARBIER, J.. (1997): Guía de Arte Precolombino. Skira Editore, Milán.

BLOCH-ALAIN, R. (1974): Las conquistas de la arqueología. Ediciones Guadarrama, Madrid.

CAMPBELL, J. (1991): En diálogo con Bill Moyers. El poder del mito. Emecé Editores, Barcelona. 
CAMPBELL, J. (1991a): Las Máscaras de Dios: Mitología primitiva. Alianza, Madrid.

CAMPBELL, J. (1992): Las Máscaras de Dios: Mitología occidental. Alianza, Madrid.

CARVAJAL T., C. A. (2003): Perseo.

http://almaak.tripod.com/temas/constelaciones/perseo.html

CELA, C. J. (1969): Diccionario secreto, I. Ediciones Alfaguara, Madrid.

CERAM, C. W. (1981): El misterio de los hititas. Ediciones Destino, Barcelona.

Cortés, M. T. G. (1993): ¿Individualidad femenina? y La violación en el filo de la navaja. Mujeres del Frente Feminista de Zaragoza. Monográfico, No 4, Zaragoza.

E. U. I. Enciclopedia Universal Ilustrada Europeo-Americana. 70 Tomos. EspasaCalpe, Madrid (Ediciones de 1930, de 1985-86, de 1991, de 1993 y de 1994).

ESCOBAR, C. (2004): Mis Dos Sonrisas. LaCuerda. Una mirada feminista de la realidad. Año 7, No 69. Guatemala, julio.

Ezra, K. (1987): África. (The Metropolitan Museum of Art. The Pacific Islands, Africa, and the Americas). Published by The Metropolitan Museum of Art, New York.

FRADE, C. (1996): Miles de años de sexo. El Mundo, Madrid, 15-12-96.

GIBERTI, Eva (2004): Reír para complacer. Publicado el 10 julio de 1998 en el Suplemento Las 12, página 12.

http://www.evagiberti.com/articulos/genero10.shtml 
GIRARD, R. (1978): Historia de las Civilizaciones Antiguas de América. Tomos I-IIIII. Hispanoamérica Ediciones, México.

GROSSATO, A. (2000): El libro de los Símbolos. Metamorfosis de lo humano entre Oriente y Occidente. Grijalvo Mondadori, Barcelona.

HERNÁNDEZ, B. (2004): De Cuaresma y Bulas. Revista Vivat Academia, Docencia e investigación. Abril 2003, No 44.

http://www2.uah.es/vivatacademia/anteriores/n44/ docencia.htm

HERRMANN, J. (1986 y 1990): Estrellas. Editorial Blume, S. A. Barcelona, Naturart, S. A. Barcelona.

HUSAIN, S. (1997): La Diosa. Debate, Madrid. Círculo de Lectores, Barcelona.

JACOBELLI, M. C. (1991): El «risus paschalis» y el fundamento teológico del placer sexual. Editorial Planeta, S. A. Barcelona.

LARA, F. (1990): Así vivían los Fenicios. Grupo Anaya, S. A., Madrid.

LÓPEZ, J. J. (2003): El JeroLítico (Edad de la Piedra Sagrada) (La Mitología como Fuente y como Llama que ilumina el Espíritu de la Piedra en la Prehistoria). http:/ / es.geocities.com/contraandrocentrismo/juanjolopez.html

MARCOS, J. G. y NORTON, P. (1984): Tesoros del Ecuador antiguo. Breve Prehistoria del Ecuador y La conexión Loma Alta. Instituto Catalán de Cooperación Iberoamericana. Museo Etnológico, Barcelona.

MARKALE, J. (1989): Druidas. Altea, Taurus, Alfaguara, Madrid. 
MARTÍN-CANO, F. (1999-2002): Fechas de situaciones estelares de días de fiesta de la religión agrícola de hace 5 milenios, desfasadas 75 días respecto a las fechas de similares eventos astronómicos actuales (ex-Calendario astronómico prehistórico). Artículo presentado en las VII Jornadas Astronómicas del Planetari de Castelló. Marzo de 1999. (Actas en prensa).

http:// personales.com/zaragoza/martincano/ca.9calendario.htm (Actualizado el 15/11/02).

MARTÍN-CANO, F. (2001): Mitos que recuerdan el matriarcado. Portal de eleusis.net: "la ciudad de las mujeres en la Red" y la morada "Si buscas chicas buenas, te has equivocado de lugar. Aquí, sólo estamos las malas".

http://www.e-leusis.net/documentos.asp

http://www.la-morada.com/mitosmatriarcado.htm

MARTÍN-CANO, F. (2001): La mujer responsable del proceso de hominización. http://es.geocities.com/culturaarcaica/1homini.html

MARTÍN-CANO, F. (2003): Contra el fanatismo de la locura androcéntrica. Leonas de Chauvet e híbridas femeninas en cuevas del Paleolítico, en donde Magas / Prêtesses / Priestess propiciaban a la Diosa Madre Naturaleza. Falsificaciones de Breuil y complicidad de seguidores.

http://es.geocities.com/martincanot/debatearqueo3.html

MARTÍN-CANO, F. B. (2004): Sexualidad en arcaicos rituales sagrados: orgías con bastones fálicos.

http://es.geocities.com/martincanot/orgiaconbaston.htm 
MARTÍN-CANO, F. B. (2004a): «Faloforias» paganas y «Risus paschalis» cristiano. http:/ / es.geocities.com/martincanot/risus_paschalis.htm

http:/ / forosmp.com.ar/phpBB2/ viewtopic.php?t=1004\&view=previous\&sid =72aba8fcd18f4712f8eb9a9f41dc1ebd

MAYR, F. K. y ORTIZ-OSÉS, A. (1989): La mitología occidental. Anthropos, Barcelona.

NADAL, V. (1999): Sekhmet: La Diosa presente.

http://www.jungba.com.ar/editorial/body_texto_editorial03.asp

ORTIZ-OSÉS, A. y MAYR, F. K. (1982): El inconsciente colectivo vasco. Txertoa, San Sebastián.

PANERO, Natalia. (2005): El arte azteca. Datafax, 2002.

http:/ / cfm.telepolis.com/monograficos/frame.cfm?link=http\%3A//www.datafax.c om.ar/arte/lecciones\%2520de\%2520arte/notas/nota3.htm

PAREDES, T. (1988): La mujer y el arte. El Punto, Madrid.

-- (1988a): I Erotismo y arte. El Punto, Madrid, del 10 al 16 de junio, pg. 12.

-- (1988b): El lenguaje perdido. El Punto, Madrid, del 25 de noviembre al 1 de diciembre, pg. 14.

PERSIO Y JUVENAL. (1982): Sátiras completas. Imprenta Juvenil, S. A. Barcelona.

PIRAS, A. (2004): Specchio delle mie brame.

http://www.fantasymagazine.it/rubriche/13 
PIRENNE, J. (1982): Historia del Antiguo Egipto. Volumen I. Ediciones Océano-Éxito, S. A., Barcelona.

ROYES y otros. (2000): La fundació de la ciutat / La fundación de la ciudad. Mesopotamia Grecia Roma. Centre de Cultura Contemporània de Barcelona. Institud d’Edicions de la Diputació de Barcelona, Barcelona.

SÁINZ DE ROBLES, F. C. (1959): Ensayo de un Diccionario de Mujeres Célebres. Aguilar, Madrid.

SOLE. (2004): Museo de Antropología e Historia. http:/ / www.inaoep.mx/ sole/turismo/DF/mini-antr.html

VÁZQUEZ, A. M. (2004). Aproximación a la Gorgona Medusa en la mitología griega y latina.

http://www.uned.es/geo-1-historia-antigua-universal/MAGIA/

GORGONA/Gorgona9texto.htm

WESTHEIM, P. (1987): Ideas fundamentales del arte prehispánico en México. Ediciones Era, México, 1972 y Alianza, S. A. Madrid.

WESTHEIM, P. (1988): Arte antiguo de México. Ediciones Era, México, 1970 y Alianza, S. A. Madrid. 